University of Pretoria etd - Cooper, J H (2005)

\title{
A TRAINING PROGRAMME BASED ON THE PRINCIPLES OF SOCIAL CONSTRUCTIVISM AND FOCUSED ON DEVELOPING PEOPLE FOR THE FUTURE WORLD OF WORK: AN EVALUATION
}

by

JEAN HENRY COOPER

Submitted in partial fulfilment of the requirements for the degree

MAGISTERS COMMERCII

in the

FACULTY OF ECONOMIC AND BUSINESS SCIENCES

at the

UNIVERSITY OF PRETORIA

PRETORIA

JANUARY 2005

Supervisor: Prof. J.S. Basson 


\section{CONCEPT DECLARATION}

I, Jean Henry Cooper, declare that "A training programme based on the principles of social constructivism and focused on developing people for the future world of work: an evaluation" is my own work. All the resources I used for this study are cited and referred to in the reference list by means of a comprehensive referencing system.

I declare that the content of this thesis/article has never before been used for any qualification at any tertiary institute. 


\begin{abstract}
Human resource development needs to take cognisance of the unique challenges the workplace of the future will pose for individuals in order to be able to effectively prepare individuals for the future. The objective of this study was to evaluate a training programme that was based on the principles of social constructivism and focused on developing people for the workplace of the future. A non-equivalent groups design with a pre-and post-measurement was used to evaluate the programme. The experimental group consisted of thirty-six individuals and the control group consisted of twenty individuals. The training programme contributed to a significant increase in the creativity, adaptability and self-acceptance of the experimental group (compared with the control group). These characteristics are necessary to succeed in the future workplace. The training programme thus made a valuable contribution to the development of the experimental group for the workplace of the future.
\end{abstract}




\section{Opsomming}

Menslikehulpbron-ontwikkeling moet ag slaan op die unieke uitdagings wat die werksplek van die toekoms aan indiwidue gaan stel ten einde hulle effektief daarvoor voor te berei. Die doel van hierdie studie was om 'n opleidingsprogram, wat op die beginsels van sosiale konstruktivisme gebaseer is en wat ten doel het om indiwidue te ontwikkel vir die werksplek van die toekoms, te evalueer. 'n Nie-ekwivalente groepsontwerp met ' $\mathrm{n}$ voor- en na-meting is gebruik om die opleidingsprogram te evalueer. Die eksperimentele groep het bestaan uit ses en dertig indiwidue terwyl die kontrole groep uit twintig indiwidue bestaan het. Die opleidingsprogram het bygedra tot ' $\mathrm{n}$ beduidende toename in die eksperimentele groep (vergeleke met die kontrole groep) se kreatiwiteit, aanpasbaarheid en self-aanvaarding. Hierdie eienskappe is noodsaaklik vir sukses in die werksplek van die toekoms. Die opleidingsprogram het dus ' $n$ waardevolle bydrae gelewer om die eksperimentele groep te ontwikkel vir die werksplek van die toekoms. 
University of Pretoria etd - Cooper, J H (2005)

\section{ACKNOWLEDGEMENTS}

In completion of this study, I would like to express my gratitude to the following individuals:

- Prof. J.S. Basson, for his guidance and patience;

- Dr. P. Schaap, for his help with the statistics;

- Spellbound Education, for their innovative approach to education and their willingness to let me conduct the study;

- My parents, for all their support and encouragement;

- Fransie, for being my wife and best friend. 
University of Pretoria etd - Cooper, J H (2005)

TABLE OF CONTENT

CONCEPT DECLARATION

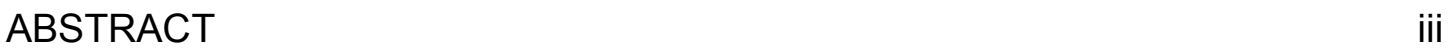

OPSOMMING iv

ACKNOWLEDGEMENTS V v

LIST OF TABLES viii

LIST OF FIGURES

CHAPTER 1: BACKGROUND AND PURPOSE OF STUDY

1.1. Introduction and background 1

1.2. Problem statement 2

1.3. Purpose of study 3

1.4. Hypothesis 3

1.5. Significance of study 4

1.6. Chapter outline 5

CHAPTER 2: THE FUTURE WORLD OF WORK

2.1. Main trends and drivers that are shaping the future 6

2.2. Expected characteristics of the future world of work 8

2.3. Characteristics of the successful individual of the future 13

2.4. Training and development in the future world of work 20

2.5. Final remarks 28

CHAPTER 3: SOCIAL CONSTRUCTIVISM

3.1. The background and development of social constructivism 29

3.2. The nature of the learner 33

3.3. The role of the instructor 35 
University of Pretoria etd - Cooper, J H (2005)

TABLE OF CONTENT (Continued)

3.4. The nature of the learning process 36

3.5. The selection, scope and sequencing of the subject matter 41

3.6. Final remarks 44

CHAPTER 4: FULL JOURNAL ARTICLE

4.1. Introduction 46

4.2. Purpose of study 47

4.3. Theoretical background 48

4.4. Methodology 54

4.5. Results 63

4.6. Conclusion 64

4.7. References 68

5. BIBLIOGRAPHY

ADDENDUM: Questionnaire 
University of Pretoria etd - Cooper, J H (2005)

\section{LIST OF TABLES}

Table 4.1: Differences between the pre- and post-evaluations of the experimental group and the control group pertaining to the constructs measured 
University of Pretoria etd - Cooper, J H (2005)

\section{LIST OF FIGURES}

Figure 4.1: The world, the workplace and the successful individual of the future

Figure 4.2: Overview of the training curriculum

Figure 4.3: Comparison between social constructivism and the training programme

Figure 4.4: Constructs measured 
University of Pretoria etd - Cooper, J H (2005)

\section{CHAPTER 1: BACKGROUND AND PURPOSE OF STUDY}

\subsection{Introduction and background}

We live in a world of rapid technological and economical change (Wagner 2002). Very few jobs are being done in the same way as they were done twenty years ago in fact many jobs we know today did not even exist twenty years ago (Marginson 2000). Twenty years ago telegrams were used to convey brief, urgent messages. Longer, formal pieces of information were sent by mail. Telephonic conversations only took place when both parties were connected via a cable telephone and very few organisations worldwide possessed computers (Koschmann 2000).

According to Geldenhuys (2004) documents of hundreds of pages in length can be sent via electronic mail to the other side of the world in an instant. Photographs, music and movies can be transmitted just as quickly. Surgeons can perform complex

medical operations without being in the same hemisphere as their patients and every household in the developed world has access to at least two computers. The word processor totally replaced the typewriter while faxes, telephone calls, photos, music and mail can be dealt with by a person who is driving or sitting on the beach. In fact, typing is hardly needed anymore as the computer can convert speech into text automatically - in any language you prefer. By means of GPS technology motorcars can find their own way in cities that you have never been to before and money can be deposited and transferred without the account-holder being close to a bank. One can buy groceries, books, cars, movie tickets and air tickets, houses, businesses and almost anything else via the internet. In fact, there is not a single industry, 
organisation or job today that has not been affected directly or indirectly by the information revolution of the past twenty years (Geldenhuys 2004).

The information industry revolution radically changed the world over the last twenty years and apparently its full force is yet to be experienced (Hiemstra 1999). And, to add to this rapid change, we are also experiencing the starting phases of the biotechnological and nano-technological revolutions today. While it took the world hundreds of years to progress from the agricultural era to the industrial era to the information era, today we are experiencing three economical and technological revolutions simultaneously (Grulke 2001).

Many aspects of our economic and personal lives have been affected over the past twenty years by technological, institutional and value changes (Ridderstråle and Nordström 2004). What will the next twenty years be like? However, if it is so difficult to know what the future will look like, how do we train and develop people for the workplace of the future? How do we prepare people for a world that does not yet exist (Cetron 1999)?

\subsection{Problem statement}

According to Moore's law, the processing power and speed of microprocessors is doubling every eighteen months (Molebash and Fisher 2003). Geldenhuys (2004) further states that bandwidth doubles every nine months. This inevitably leads to a situation where knowledge is shared and expanded at an exponentially increasing rate, and new technologies that nullify old skills are being introduced to the market 
University of Pretoria etd - Cooper, J H (2005)

rapidly (Ridderstråle and Nordström 2004). This poses some unique new challenges to education and training. Knowledge and skills that are acquired today may be obsolete tomorrow while we do not even know exactly which new skills will be needed to replace the old ones.

The research problem is how to train and develop people to succeed in the world of work of the future.

\subsection{Purpose of study}

The purpose of the study is to evaluate the effectiveness of a training programme that focuses on developing people for the future workplace. The training programme is based on the principles of the educational theory social constructivism.

\subsection{Hypothesis}

As stated previously, the workplace of the future will be characterised by an abundance of information that is accessible to everyone (Marginson 2000). Knowledge and technology is also expanding exponentially, which makes current knowledge outdated, and current skills are obsolete by tomorrow (Hiemstra 1999). Furthermore, it is expected that healthy business relationships across a wide network will be an invaluable asset in the future economy (Epstein 1998).

Because of these characteristics that are expected of the future economy, it could be deduced that one should prepare individuals to confront these specific challenges. If 
knowledge expands continually, one should not focus on transferring specific knowledge, but rather on the ability and motivation to continually acquire new knowledge and skills (Brownstein 2001). If relationships are vitally important for future success, one should focus on developing characteristics in individuals that are conducive to healthy, valuable relationships (Ridderstråle and Nordström 2004).

As social constructivism emphasizes interactive, relational learning and selfdiscovery (Holt and Willard-Holt 2000), it is hypothesized that this specific social constructivist learning intervention will have a positive impact on the participants with regard to the characteristics needed for success in the future workplace.

The zero-hypothesis is that no positive change will take place in the participants and the alternative hypothesis is that the learning intervention does indeed effect a positive change in participants.

\subsection{Significance of study}

This study strives to make a valuable contribution to understanding how to develop people for the workplace of the future. Firstly it is significant as it explores the nature of the future workplace as well as the individual that will most probably succeed in that environment. Secondly it is significant as it unpacks the theory and principles of social constructivism against this backdrop. Thirdly it is significant in that it practically evaluates a learning intervention that is based on social constructivist theory and that focuses on developing people for the future workplace. Finally it is significant because it suggests further avenues of thought and research that might contribute to 
University of Pretoria etd - Cooper, J H (2005)

this critically important dialogue: How do we prepare people for the workplace of the future?

\subsection{Chapter outline}

The following chapter explores different scholars' views pertaining to the world of the future, the workplace of the future and the individual that is most likely to succeed in this workplace. Chapter 3 focuses on the development and principles of social constructivism. Chapter 4 is a full academic article that encompasses the entire literature review, research methodology, results, conclusions and recommendations for future research. 
University of Pretoria etd - Cooper, J H (2005)

\section{CHAPTER 2: THE FUTURE WORLD OF WORK}

\subsection{Main trends and drivers that are shaping the future}

There are many trends and drivers shaping the future, and subsequently the future of the workplace as well. In many of the stories foretelling the future of work, technology is assumed to be the irresistible driver of change (Marginson 2000). Institutions and values are also changing to such an extent that these factors are also having an increasing impact on the workplace (Ridderstråle and Nordström 2004). According to Wagner (2002), issues such as genetic engineering and artificial intelligence are examples of technologies that will dramatically transform society in the future.

According to Wolfgang Grulke (2000), we are currently in a unique situation in history. He emphasizes the simultaneous explosion of various economical and technological revolutions. It took the world hundreds of years to move from the agricultural economy through the industrial revolution; yet the rise of information technology, biotechnology and nanotechnology are experienced all at once.

Although it is true that technologies like genetic engineering, nanotechnology and artificial intelligence are factors that might totally change the way in which we work and live, one only needs to examine the effects of current, commercial technologies to become aware of some of the possible characteristics of the future world (Koschmann 2000). Without citing probable innovations that might sound more like 
University of Pretoria etd - Cooper, J H (2005)

science fiction than anything else, one can still expect a rapidly changing future just by focusing on current technologies like telecommunications and the internet.

Moore's law states that the processing speed and power of the microprocessor is doubling every eighteen months (Molebash and Fisher 2003) and Geldenhuys (2004) estimates that bandwidth is doubling every nine months. Information and knowledge are thus being processed and shared faster and amongst a wider community than ever before, which fuels the rapid rate of change and innovation. These technologies are truly changing our world (Hiemstra 1999). If we dare to remember what the world looked like without cell phones only ten tears ago, and we dare to imagine what it will be like in ten years' time, we realise the immensity and speed of the change that awaits us (Grulke 2001).

Besides the technological advancements that are possible and/or probable in the near future, political, social and philosophical developments are also inevitable (Ridderstråle and Nordström 2004). It is clear that, besides the fact that knowledge can be transmitted and processed much faster and much more efficiently than ever, distances between people, cities, countries and hemispheres are diminishing bringing people of various cultures, languages and backgrounds closer together than ever before in history (Kerka 2000). 
University of Pretoria etd - Cooper, J H (2005)

\subsection{Expected characteristics of the future world of work}

\subsubsection{Introductory thoughts}

If the world of the future is one in which changes and improvements to the ways things are being done and understood are happening faster than ever before, what will the workplace of the future look like? If "workplace" is defined as the place where people get together to work and add economic value, it becomes clear that communication and information technologies like the internet, laptop and handheld computers, cell phones and wireless applications will have an ever-increasing impact on the way the workplace is organised (Drucker 1998).

\subsubsection{Flexible work arrangements}

According to Koschmann (2000) work will move to unconventional sites and arrangements. Employers are willing to consider almost any work arrangement that will get work done at less cost (Wagner 2002). During the early nineties, Coates, Jarrat and Mahaffie (1991) already observed that businesses were seeking to contain costs and were responding to the need for flexibility to meet sudden demands or slowdown in work. They noted that workers with critical skills were also either too scarce or too expensive to hire full time and that workers, on the other hand, found flexible schedules appealing, particularly in terms of childcare, and were more concerned about such factors as long commutes. According to Challenger (1998) the U.S. Bureau of Labour Statistics projects 151 million jobs by 2006 and 141 million people employed, showing an increasing number of people doing more 
than one job. Furthermore, he states that it is increasingly becoming obvious that employees need not always be at a predetermined location to get the job done. (Challenger 1998).

\subsubsection{Smaller organisations, stronger relationships}

As rapid change and chaotic uncertainty are becoming an integral part of doing business, the organisation that wants to survive the future, needs to be able to embrace chaos and be radically innovative about doing everyday business (Grulke 2001). In order to accomplish this, organisational structures need to change. Organisations need to be nimble, quick and extremely resilient (Ridderstråle and Nordström 2004).

In an article titled "The relationship economy", Jeffrey Epstein explains why executives are expecting more alliances and smaller headquarters (Epstein 1998). The company of the future will be a lean organisation drawing on a network of external relationships (Epstein 1998). He also emphasizes that effective communication and people skills are what will be needed for success in 2010 and beyond.

Epstein (1998) further predicts that, within 20 years, the company of the future will consist of a small team running its affairs from a single office. A team that will build and use its knowledge of market demands and customer requirements, potential suppliers and partners, and bring them together through sophisticated electronic links to respond quickly and painlessly to changes in fashion and economic 
circumstance. He poses that the process of creating value will be set free from all unnecessary activities, and for that reason alone, it will be significantly more efficient.

During the eighties and nineties it was clear that organisations reduced management layers in order to improve efficiency. Challenger (1998) shows that most management layers were downsized out of American corporations during the 1990s. This left fewer managers to report to and fewer decisions that require their input, thus increasing the speed of decision-making and the overall efficiency of the smaller organisation (Challenger 1998). Coates, Jarrat and Mahaffie (1991) also reported on this trend and observed that corporations were cutting the layers of managers that separate top executives from other workers, saying that, between 1980 and 1987, eighty-nine of the top 100 U.S. companies reduced their management layers and that an analysis of performance showed that companies with only seven layers perform better than those with eleven (Coates, Jarrat and Mahaffie 1991).

Today we have moved beyond this scenario to one where every business activity that does not form part of the organisation's core focus, is being outsourced to business that can perform those tasks more efficiently - leaving a lean and streamlined organisation that focuses on managing and nurturing relationships with business partners (Bass 2000). Divisions that provided support services to large corporations, will now operate as separate businesses and also sell their services to other clients. It is clear that the relationships are changing from manager-employee to business partners or client-supplier (Ridderstråle and Nordström 2004). In a research project that included interviews and focus groups with business and academic leaders, 350 senior executives and directors around the world suggested 
University of Pretoria etd - Cooper, J H (2005)

that the trend toward more outsourcing and partnerships will have even broader impacts in the future, and managing those relationships will be crucial for business success (Epstein 1998). Epstein (1998) suggests that all these relationships will require thoughtful planning and constant attention in order to work optimally.

Furthermore, many executives anticipate their organisation becoming more virtual in the coming years, but they also see some obstacles to getting there, such as the difficulty of managing people effectively and the problem of maintaining clear and frequent communications (Epstein 1998).

In a world where individuals operate as fractal entities, servicing different clients as part of dispersed work teams, new challenges emerge to create an esprit de corps amongst team members. As early as 1998, Challenger believed that this need will be serious enough to create a new job category: the director of socialisation, who will be responsible for helping workers connect with each other while giving them an opportunity to express themselves to someone other than the boss.

Another characteristic trend of the future relationship-economy, is that competitors, too, sometimes become vendors for each other in some areas. They can even become partners in joint ventures or form temporary alliances where they can accomplish more together than alone (Epstein 1998). 


\subsubsection{Valuing and investing in human capital}

More than ever before, people are the dominant factor in both service and production. People plan, invent, design, operate, manage and service the large corporation. People are the suppliers and the customers of the large corporation. Herman and Gioia (1998) highlight that, through their knowledge and experience, workers can provide the organisation with a wealth of information that cannot be acquired elsewhere. In order to tap this intellectual capital, the organisation must create a culture that encourages and supports collaboration. Effective collaboration will stimulate ideas and give the platform for creative synergies to emerge (Cetron 1999).

This increased attention being given to the demand for more productive and more effective workers is stimulating new ideas pertaining to innovation with regard to strategies in human resource management (Brownstein 2001). When one thinks of innovation, one tends to think of science and high technology, such as robots and new ceramics. But now one also thinks of quality circles, innovative rewards, and new work arrangements. Grulke (2001) explains that innovation is not the invention of a new tool, but the creative new use and alteration of existing technologies. This means that organisations are beginning to implement radical new and creative solutions for attracting, managing, rewarding and developing their people by taking existing methods and applying them in new contexts and ways.

It is also imperative to emphasize the importance of training and development in the future world of work (Brownstein 2001). If an organisation wishes to remain 
competitive it needs to be able to develop skills and knowledge to keep up with technological changes and demands. Most people will have to continuously learn new skills (Cetron 1999).

Where organisations become smaller and organisational structures become flatter and more flexible, workers also need to be empowered to manage themselves and their own deliverables. The concept of empowering workers has left an indelible mark, not only on the workforce, but on the marketplace as well (Kerka 2000). Where players in the new economy are more likely to come into direct contact with the customer as opposed to a line of superiors in a huge corporation, it becomes imperative to satisfy an unrelenting consumer who wants more products and services faster and at a better price (Ridderstråle and Nordström 2004). Worker populations will need to be better prepared for this kind of demand and only those adequately educated will be able to handle the ever-changing technology designed to help us compete effectively in a market of world consumers (Brownstein 2001).

\subsection{Characteristics of the successful individual of the future}

This section contains a selection of descriptions scholars chose to depict the individual that will be able to thrive in the economy of the future. It is interesting to note that much more emphasis is being placed on the development of certain characteristics and skills than the acquiring of specific knowledge. In a world where information is available everywhere and accessible to everyone, knowledge does not give one the competitive advantage anymore (Ridderstråle and Nordström 2004). 
Today, and even more so tomorrow, it will not be the knowledge per se but the ability to convert that knowledge into value that will make the difference (Grulke 2000).

Ridderstråle and Nordström (2004) argue that the new focus on workers as an asset will make attitudes and values more central. Pressed by demands for an adequate return on investment in the workforce, managers are becoming increasingly concerned about factors shaping their employees' behaviour. More is being invested in training. Yet at the same time, the workforce is increasingly diverse in its attitudes and lifestyles.

In addition to this, Herman and Gioia (1998) state that the top employees of the coming century will be flexible, creative, and motivated towards making a positive difference in the world. These are, however, only but a few of the characteristics that will prepare an individual for the demands of the future.

\subsubsection{Passion for learning}

Skills critical to the future of the workplace are emerging, but some are or will be in short supply (Molebash and Fisher 2003). Several factors are driving the shift toward new skills for work: greater use of information technologies, the move away from craft and assembly manufacture and toward computer-mediated processes, the larger amount of knowledge-work in almost every occupation, new requirements for education and the ability to manage complexity, and the redesign of many jobs to include computer-based work (Cetron 1999). Frequently, several skills will be folded 
into one job, often with a new title and greater individual responsibility (Brownstein 2001).

Except for the fact that continuous changes in the work environment will require workers to continuously develop new skills or enhance and adapt their old ones, the mere fact of the explosion of knowledge also requires hard work and dedication from individuals who want to be in demand. The individual that has a passion for learning and a natural curiosity will have the edge. The employee of the future will be passionate and adamant about continuous self-improvement in order not to fall behind (Senge 1993).

However, this continuous learning does not necessary mean continuous formal education. It also does not refer to the rote memorisation of new facts and figures. It refers to the drive and ability to make sense out of facts - being able to grasp the underlying principles and seeking synergy between different sets of knowledge, value and people. The individual of the future will need to gain insights from experiences and trends and develop visionary abilities (Marginson 2000).

To have a passion for learning also entails a passion for wisdom: the desire to know the right way, as well as the decisiveness to choose the right way. It seems as if the literature suggests that one does not only need the passion for learning about one's work or speciality, but also the passion to learn about life and how to live it (Branden 1997; Boyatzis 1999; Humphreys 2003). There is a definite trend towards the spiritual, and the search for meaning and popular self-help literature attest to this (Koschmann 2000). This continuous focus on improvement and development will 
create an effective and whole individual that will be able to meet the demands of a rapidly changing environment (Ridderstråle and Nordström 2004).

Except for having a passion for her/his own learning, the individual of the future also needs to have a passion for the growth and development of her/his team. Future individuals need to communicate their insights, ideas and visions to their teams or networks in order to reap maximum benefits from continuous learning (Senge 2000). Individuals thus need to have a passion and curiosity for learning, developing and continuously acquiring new skills, as well as the ability to internalise this learning and create value from it, and finally the additional ability to transfer these skills and knowledge to team members, superiors and subordinates.

\subsubsection{Confidence}

Knowledgeable, confident workers are essential for the lean and meaningful companies of the future (Pickett 1998). Encouraging innovation and entrepreneurship is the new goal of corporate management. Following the examples of many smaller companies, large organisations are also experimenting with empowering their workers. To some, this is an old idea - a good business practice with a new name. Driving the recycling of this idea are the greater use of worker participation as a tool for generating productivity, information technology that makes information available at all levels of an organisation, and a better-educated workforce, among other factors (Brownstein 2001). 
The individual of the future needs to be self-reliant. This does not refer to individualism versus interdependence amongst team members, but to an inner security that springs from the individual's mastery of him/herself. Individuals need to know themselves, their strengths, weaknesses and goals (Branden 1997). They also need to keep the various aspects of their lives in balance.

This level of inner mastery will provide the individual with a sense of security within the self that will form a firm foundation for being assertive and optimistic about various situations (Land and Jarman 1992). A sense of inner mastery and inner security will also enable an individual to develop a crucial attribute for survival in the future, namely opportunity-orientation. Individuals will need the ability to seek and spot opportunities as well as the risk proneness to pursue them (Kerka 2000).

\subsubsection{Motivation}

A high degree of internal motivation improves one's chances of thriving in the new world of work (Marginson 2000). Specific traits associated with motivation, are tenacity, self-discipline, focus and energy (Porter 1968). The employee of the future will most likely be employed by him/herself or by a small, fast-moving company (Grulke 2000). The ability to be motivated will provide the drive and momentum necessary to pull others along as well. In an uncertain environment with continuous challenges, the self-discipline to endure will be imperative (Koschmann 2000). Furthermore, one does not only need to be able to pull through; one's motivation needs to be of such a level that one is continuously inspired to pro-actively engage with the challenges of everyday life (Branden 1997). This pro-active approach will 
pre-empt change and come naturally to one who is inspired, motivated and passionate.

\subsubsection{Passion for change}

In order to excel in the future world of work, one needs to be passionate about change (McGinn and McCormick 1999). It is not about being able to cope with change; it is about embracing change and creating change (Boyatzis 1999). Risks will increase and therefore a proneness for risk-taking will be highly beneficial.

The reshuffling of jobs will create a new business culture in which most people, as well as having more than one career, will have been laid off, or retrenched, at least once, can expect to be laid off again, and are likely to behave as if their current jobs are fleeting. In order to thrive in this environment one needs to be flexible and adaptable (McGinn and McCormick 1999). One also needs to know where to source security from, as it is no longer going to come from one's job.

\subsubsection{Kindness / Compassion}

An interesting attribute necessary for functioning in the workplace of the future, is kindness. Some scholars refer to compassion or tenderness while others simply call it love. When thinking about this attribute, words like charitability, humility, lightheartedness and appreciation are also used in the literature (Humphreys 2003). 
In a world where business and work will depend more and more on relationships and the way one manages those relationships, one begins to understand the value of these "softer" attributes (Epstein 1998, Rhodes and Garrick 2002). Seeking the best interest of the other party and going out of one's way to serve are all connected to the concept of kindness (Humphreys 2003). These acts of kindness or love are seen as possible major investments in future relationships (Epstein 1998).

With the rising importance of ethics, following the guidelines of love might also prove invaluable for the future of business as well as society at large (Chewning et al.1990).

\subsubsection{Integrity}

According to the literature, concepts such as integrity, authenticity, honesty and consistency will gain higher importance in future (Epstein 1998). These are all crucial ingredients in managing networks and relationships. Once a person's integrity is in doubt, it will be almost impossible to do business within one's existing network again. In an economy based on relationships and networks, this will be economical suicide (Humphreys 2003).

Integrity means that people know where they stand with a particular individual. It means that one is consistent in what one promises and delivers. It also refers to being reliable and trustworthy. All these things are crucial for making any relationship work (Boyatzis 1999). 
University of Pretoria etd - Cooper, J H (2005)

Closely related to integrity, is ethics - to know the right thing to do. Scholars have argued that it will be impossible to survive the twenty-first century with the ethics of the twentieth (Chewning et al. 1990). Arguments are being raised that the movement of women into executive positions can overcome these problems as they are more focused on relationships, and less on executive greed (Epstein 1998).

\subsection{Training and development in the future world of work}

In the following section attention is given to some of the most important issues regarding preparing individuals for the workplace of the future:

What are the demands that the workplace of the future will place on education and training? Who will need to take ownership of the education and training process? What are the core focus areas that need to be addressed in curricula of the future? In which format should education and training be conveyed in order to effectively prepare individuals for the future world of work?

All these questions are addressed in what follows, although more in-depth answers will be sought in the following chapter.

\subsubsection{The need for education and training in the future}

In a world where information and knowledge are expanding rapidly, it is no surprise that a renewed emphasis is being placed on education and training. In corporations today, training budgets are expected to remain high as they stretch for new results. 
University of Pretoria etd - Cooper, J H (2005)

To boost competitiveness, many corporations are energetically training and retraining their workforces (Marginson 2000).

Challenger (1998) warns that corporations that do not invest in education, will suffer serious consequences. He says that it is not only about committing money to education, but educational standards and practices should be created to prepare the next generation for the future.

The increasing attention that corporations are giving to education and training, makes it obvious that the need for educating the workforce is being felt. From the discussion in the first section of this chapter it is also evident that education and training are becoming ever more vital for future success. As stated earlier, the massive technological advances and new communication methods are asking for leaner, meaner organisations that can keep up with the tempo of change and development in the economy. In order to drive this change, the intellectual capital of the individual in the small organisation is becoming the single most important asset of the company (Ridderstråle and Nordström 2004). From this flows the natural conclusion that investment in this intellectual capital will become the lifeblood of the successful organisation of the future, thus increasing the need for sufficient and continuous education and training.

\subsubsection{The responsibility for education and training}

Training will become the next boom industry as employers are forced to take on the responsibility of educating unskilled workers. Challenger (1998) feels that employers 
University of Pretoria etd - Cooper, J H (2005)

will need to become the public schools of the next generation over the next 25 years. Workers will be more independent and self-directed, and companies will need to form partnerships with educators to prepare young people for the high-tech workplace (Koschmann 2000).

In such an environment, employees are as mobile as their employers, which means that offering training or other career enhancements may be necessary to recruit and retain good workers. Assurances of long-term employment or defined career paths within the organisation are far less important to employees in this environment than career paths they can control, and individual training that enhances their career potential (Epstein 1998).

However, although organisations do take responsibility for continuously educating their workforce, it remains the responsibility of the individual to take ownership of his/her own education and development. In the previous section it was argued that a passion for learning is one of the prerequisites for being successful in the workplace of the future (Ridderstråle and Nordström 2004). This passion for learning means a lifelong commitment from the individual to keep up with technological advancements and change. Only the individual who is willing to take ownership for learning will truly benefit from the organisation's assistance in providing the training opportunities (Senge 2000). 


\subsubsection{Areas to be focused on when educating and training individuals for the future}

The previous section indicated the main qualities needed to survive and thrive in the workplace of the future. If the training and education that individuals are exposed to are to be of any relevance for the future, these need to develop specific traits, qualities and skills in individuals.

The educational system should create individuals who can operate in the real world: Individuals who know who they are and where they are going; individuals who have a passion for learning and developing themselves; individuals who embrace change and who are all right with uncertainty; individuals who have integrity and strong ethics and who can engage in and manage good and healthy relationships; individuals who ask: "How can I serve others? How can I add value to others' lives?"; individuals who are motivated and confident that they will overcome the obstacles and challenges of the future (Senge 2000).

But how does one develop all these characteristics? What should a learning system look like that will ignite and foster development in these dimensions rather than just focusing on conveying a body of knowledge (Cetron 1999)?

\subsubsection{Perspectives on educational and training methodologies for preparing people for the future.}

The above sections tried to provide answers to the following questions in order to paint the picture of training and developing people for the future world of work: What 
does the world of the future look like? What does the subsequent workplace of the future look like? What should the individual who wishes to succeed in this workplace of the future look like?

At this point it is important to answer the following question: How should we go about training these future successful individuals? In order to try to answer this question, several perspectives need to be taken into account. When talking about training people for the future world of work, one immediately talks about a multi-disciplinary endeavour. Areas and fields of study that need to be taken into account are the social sciences, management sciences, psychology, education, philosophy and future studies (Brownstein 2001). Because of this multi-dimensional character of the topic at hand, the following section contains different perspectives on the issue of preparing individuals for the future.

In an article titled "Future Pull - The power of vision and purpose", George Land and Beth Jarman (1992) stress the importance of developing a strong sense of purpose in individuals. Although the authors do not give a clear-cut recipe as to how one should go about in creating or discovering this purpose, it is hinted that the answer does not lie in a mechanistic approach to development. There is no recipe for finding one's purpose, and writing examinations on vision and purpose will not suffice.

Finding and living one's purpose is an active and interactive process full of unanswered questions and grey areas. The "messy" aspects of this process should be embraced, rather than being analysed into a formula. 
University of Pretoria etd - Cooper, J H (2005)

James J. Heckman (1999) makes the case for a review of the educational system by referring to three blind spots in current (historical) educational thinking. In an article named "Doing it right: Job training and education, 1999" he starts his argument by emphasizing that learning is a lifetime affair and that one should not underestimate the importance of the social aspects involved when learning skills. The three blind spots he refers to are:

- The importance of informal social settings (specifically within the family) as part of the educational process, which is mostly neglected by educational policy-makers.

- The belief that academic cognition examinations serve as adequate measurement of educational intervention.

- The lack of trust in parents' ability to choose the right education and educational institution for their children.

In "The "E" Is For Everything: E-Commerce, E-Business, and E-Learning in the Future of Higher Education", (Katz 2000) the editors cite a Fortune columnist who recently wrote that the "e" in e-business will soon be irrelevant - and presumably dropped - because the only businesses to survive will be e-businesses. Although some people believe that such pronouncements are "hype," others feel that even if e-business is a bandwagon, institutions of every sort should get on board, and quickly. The authors represented in this book are definitely in the latter category. The problem, as they see it, however, is that most university administrators either cannot see the bandwagon coming or are not spry enough to climb aboard. 
University of Pretoria etd - Cooper, J H (2005)

The potential of online education, or e-learning, as the educational solution for the future is highlighted. Specific reference is being made to the need for universities to become involved in e-business in order to survive the future. Not so much emphasis is being laid on the educational dynamics needed for the future as on the essential business requirements for the management of academic institutions.

However, in "The online education bubble" (Green 2000) the author makes the point that, although online education seemed to be the next big business revolution, everything is not as rosy as it seems. He raises some concerns regarding the sustainability of online education business models, but also quotes educational experts who feel that the e-learning revolution is driven more by money than pedagogical motives. He predicts a fall in this industry similar to the other e-business bubbles that burst.

Another educational approach propagated for preparing individuals for the future, is partnership education. Partnership education, according to Riane Eisler (2000), is not just one more programme or method, but a new learning tapestry for the school of the future. Partnership education integrates three core components: partnership process, structure, and content (how, where, and what we learn and teach). It is an educational approach to help children to not only navigate themselves better through current difficult times but also to create a future that is oriented more to a partnership rather than a dominator model.

In an article titled: "Let's Get Real - Students Solving Authentic Corporate Problems", Dan G. Holt and Colleen Willard-Holt (2000) describe an educational programme 
called: Let's Get Real. The programme focuses on getting learners involved in real life problem-solving experiences. Authentic problems from corporations are put before students and they are required to come up with solutions to each problem. After their solution attempt, they also get a chance to speak to the relevant business leaders in order to learn what was done in the real scenario and the effects thereof.

In "Alternative visions for the university of the future", Jennings (2001) challenges the conventional wisdom that it takes a small village - the college campus - to produce a college graduate. It is stated that this model has changed surprisingly little from that which emerged 1,000 years ago in medieval Europe and that professors lecture, while students listen, ask questions, and are tested on how well they remember their professors' words. However, a millennium later, times have changed. Jennings (2001) observes that the thousand-year-old ideal of the campus as a village-paced community for scholarship, discussion, and research is eroding.

Jennings (2001) offers a few different possibilities for the universities of the future. He first discusses the possibilities of the Internet University together with its limitations and pitfalls. The learning methods of rote memorisation of facts also come under discussion, and ways are mentioned to enrich the learning experience. According to the author, university professors should take on the roles of knowledge brokers, mentors and sages who will guide students through acquiring knowledge and applying it in real life. 


\section{University of Pretoria etd - Cooper, J H (2005)}

\subsection{Final remarks}

This chapter explored the world of the future and the individual who will most likely be capable of surviving in that world. This chapter also superficially explored different ways in which to educate and train people for the world of work of the future. In the following chapter special attention is given to an educational model, called Social Constructivism. This educational model is being proposed as an option when talking about training individuals for the future. 
University of Pretoria etd - Cooper, J H (2005)

\section{CHAPTER 3: SOCIAL CONSTRUCTIVISM}

\subsection{The background and development of Social Constructivism}

\subsubsection{From traditional education to cognitive constructivism}

The constructivist movement has grown essentially from dissatisfaction with educational methods where rote memorisation, regurgitation of facts and the division of knowledge into different subjects, led to a situation where learners were not necessarily able to apply what they have learned in real life (Dixon-Kraus 1996). As early as 1929, Alfred North Whitehead argued that the way students learn many things in school produces inert knowledge - knowledge that can be used to answer items on a school test but which is not available to the student when he or she is trying to solve a problem that requires that knowledge (Flavell and Piaget 1963).

Furthermore, in traditional rationalist and behaviourist approaches, instruction is focused on covering an extensive subject area, reducing the amount of time for problem-solving and thinking beyond the facts, thus minimising independent and autonomous learning. It also encourages didactic lecture formats rather than active student learning (Holt and Willard-Holt 2000). This fundamental problem led to the viewpoint that instructors should only provide appropriate learning situations that will allow students to develop their own knowledge, meaning and truth that will be useful in later life. Providing a problem-solving context for actively engaging students in the thoughtful application of knowledge is an important variable in increasing learning (McMahon 1997). 
University of Pretoria etd - Cooper, J H (2005)

This educational viewpoint is called cognitive constructivism and was derived from the work of Piaget (Flavell and Piaget 1963). It defines learning as an internal process of accommodation, assimilation, and equilibration (Flavell and Piaget 1963). Piaget thus saw learning as a process where an individual constructs his or her own meaning through cognitive processes. The main underlying assumption of constructivism is that individuals are actively involved right from birth in constructing personal meaning that is their own personal understanding from their experiences (Flavell and Piaget 1963). This action-based theory is thus more concerned with the process of learning than with what is learned (McMahon 1997). Constructivism thus goes beyond the study of how the brain stores and retrieves information to examine the ways in which learners make meaning from experience (Savery 1994). Rather than the transmission of knowledge, learning is an internal process of interpretation: learners do not transfer knowledge from the external world into their memories, rather, they create interpretations of the world based upon their past experiences and their interactions in the world. How someone construes the world, their existing metaphors, is at least as powerful a factor influencing what is learned as any characteristic of that world (McMahon 1997).

Most cognitive theories, and the constructivist approaches that have grown out of these, argue that learning should be durable, transferable and self-regulated (Di Vesta 1987). Mechanisms need to be in place to promote the deeper internal processing required for such learning to occur. 


\subsubsection{From cognitive constructivism to social constructivism}

These thoughts on learning, which we now call cognitive constructivism, paved the way for the emergence of the educational theory called social constructivism (McMahon 1997). Lev Semenovich Vygotsky (1896 - 1934), a Belarusian psychologist who lived and worked in a Marxist environment, became famous for his view on mediation as an integral part of human psychology: "the central fact about our psychology is the fact of mediation" (Vygotsky 1978:166). Although his work only became known during the 1960s, his critique on his contemporary Piaget's cognitive constructivism, led to the understanding of the importance of culture, language and context in the process of constructing knowledge. Where Piaget argued that people should create their own version of the truth, Vygotsky added the importance of discussing this version of truth with others, in order to, through the process of mediation, get to a higher order of truth that has also been socially tested (Derry 1999). Vygotsky's "zone of proximal development" is probably his best-known concept. It argues that students can, with help from adults or peers who are more advanced, master concepts and ideas that they cannot understand on their own. Again the emphasis falls on learners actively constructing knowledge and meaning through participating in activities and challenges, with the added emphasis on the interaction between learners and facilitators in order to arrive at a higher level of truth (Sternberg and Williams 1998). 


\subsubsection{A practical definition of Social Constructivism}

Social constructivism argues that the most optimal learning environment is one where a dynamic interaction between instructors, learners and tasks provides an opportunity for learners to create their own truth due to the interaction with others. Social constructivism thus emphasizes the importance of culture and context in understanding what is happening in society and constructing knowledge based on this understanding (Derry 1999; McMahon 1997).

Paul Ernest (1991) summarises the main foundations of social constructivism as follows:

- Knowledge is not passively received but actively built up by the cognizing subject.

- "The function of cognition is adaptive and serves the organisation of the experiential world, not the discovery of ontological reality" (Von Glasersfeld 1989:182)

- The personal theories which result from the organisation of the experiential world must fit the constraints imposed by physical and social reality.

- This is achieved by a cycle of theory-prediction-test-failure-accommodationnew theory.

- This gives rise to socially agreed theories of the world and social patterns and rules of language use. 
University of Pretoria etd - Cooper, J H (2005)

In what follows, social constructivism is examined in more detail with specific reference to the way social constructivism views the nature of the learner, the role of the instructor, the learning process and the selection, scope and sequencing of the subject matter.

\subsection{The nature of the learner}

\subsubsection{The learner as a unique individual}

Social constructivism views each learner as a unique individual with unique needs and backgrounds. The learner is also seen as complex and multidimensional (Gredler 1997). Social constructivism not only acknowledges the uniqueness and complexity of the learner, but actually encourages, utilises and rewards it as an integral part of the learning process (Wertsch 1997).

\subsubsection{The importance of the background and culture of the learner}

Gredler (1997) also emphasizes the importance of the background and culture of the learner. Social constructivism encourages the learner to arrive at his or her own version of the truth, influenced by his or her background, culture or embedded worldview. Historical developments and symbol systems, such as language, logic, and mathematical systems, are inherited by the learner as a member of a particular culture and these are learned throughout the learner's life. These symbol systems dictate how the learner learns and what is learned (Gredler 1997). This also stresses the importance of the nature of the learner's social interaction with knowledgeable 
members of the society. Without the social interaction with other more knowledgeable people, it is impossible to acquire social meaning of important symbol systems and learn how to utilise them. Young children develop their thinking abilities by interacting with adults. From the social constructivist viewpoint, it is thus important to take into account the background and culture of the learner throughout the learning process, as this background also helps to shape the knowledge and truth that the learner creates, discovers and attains in the learning process (Gredler 1997; Wertsch 1997).

\subsubsection{The responsibility for learning}

Furthermore, it is argued that the responsibility of learning should reside increasingly with the learner (Von Glasersfeld 1989). Social constructivism thus emphasizes the importance of the learner being actively involved in the learning process, unlike previous educational viewpoints where the responsibility rested with the instructor to teach and where the learner played a passive, receptive role. Von Glasersfeld (1989) emphasizes that learners construct their own understanding and that they do not simply mirror and reflect what they read. Learners look for meaning and will try to find regularity and order in the events of the world even in the absence of full or complete information.

\subsubsection{The motivation for learning}

Another crucial assumption regarding the nature of the learner, concerns the level and source of motivation for learning. According to Von Glasersfeld (1989) 
motivation to learn is strongly dependent on the learner's confidence in his or her potential for learning. These feelings of competence and belief in potential to solve new problems, are derived from first-hand experience of mastery of problems in the past and are much more powerful than any external acknowledgement and motivation (Prawat and Floden 1994). This links up with Vygotsky's "zone of proximal development" (Vygotsky 1978) where learners are challenged within, yet slightly above their current level of development. By experiencing the successful completion of challenging tasks, learners gain confidence and motivation to embark on more complex challenges.

\subsection{The role of the instructor}

\subsubsection{Instructors as facilitators}

According to the social constructivist approach, instructors have to adapt to the role of facilitators and not teachers (Steffe and Gale 1995). Where a teacher gives a didactic lecture which covers the subject matter, a facilitator helps the learner to get to his or her own understanding of the content. In the former scenario the learner plays a passive role and in the latter scenario the learner plays an active role in the learning process. The emphasis thus turns away from the instructor and the content, and towards the learner (Kukla 2000). This dramatic change of role implies that a facilitator needs to display a total different set of skills than a teacher (Brownstein 2001). A teacher tells, a facilitator asks; a teacher lectures from the front, a facilitator supports from the back; a teacher gives answers according to a set curriculum, a facilitator provides guidelines and creates the environment for the learner to arrive at 
his or her own conclusions; a teacher mostly gives a monologue, a facilitator is in continuous dialogue with the learners (Rhodes and Bellamy 1999). A facilitator should also be able to adapt the learning experience 'in mid-air' by using his or her own initiative in order to steer the learning experience to where the learners want to create value.

The learning environment should also be designed to support and challenge the learner's thinking (Di Vesta, 1987). While it is advocated to give the learner ownership of the problem and solution process, it is not the case that any activity or any solution is adequate. The critical goal is to support the learner in becoming an effective thinker. This can be achieved by assuming multiple roles, such as consultant and coach.

\subsection{The nature of the learning process}

\subsubsection{Learning is an active, social process}

Social constructivist scholars view learning as an active process where learners should learn to discover principles, concepts and facts for themselves, hence the importance of encouraging guesswork and intuitive thinking in learners (Brown et al.1989; Ackerman 1996; Gredler 1997). In fact, for the social constructivist, reality is not something that we can discover because it does not pre-exist prior to our social invention of it. Kukla (2000) argues that reality is constructed by our own activities and that people, together as members of a society, invent the properties of the world. 
University of Pretoria etd - Cooper, J H (2005)

Other constructivist scholars agree with this and emphasize that individuals make meanings through the interactions with each other and with the environment they live in. Knowledge is thus a product of humans and is socially and culturally constructed (Ernest 1991; Gredler 1997; Prawat and Floden 1994). McMahon (1997) agrees that learning is a social process. He further states that learning is not a process that only takes place inside our minds, nor is it a passive development of our behaviours that is shaped by external forces and that meaningful learning occurs when individuals are engaged in social activities.

Vygotsky (1978) also highlighted the convergence of the social and practical elements in learning by saying that the most significant moment in the course of intellectual development occurs when speech and practical activity, two previously completely independent lines of development, converge. Through practical activity a child constructs meaning on an intrapersonal level, while speech connects this meaning with the interpersonal world shared by the child and her/his culture. Learning thus first takes place on the intrapersonal and then on the interpersonal level (Vygotsky 1978).

\subsubsection{The dynamic interaction between task, instructor and learner}

A further characteristic of the role of the facilitator in the social constructivist viewpoint, is that the instructor and the learners are equally involved in learning from each other as well (Holt and Willard-Holt 2000). This means that the learning experience is both subjective and objective and requires that the instructor's culture, values and background become an essential part of the interplay between learners 
University of Pretoria etd - Cooper, J H (2005)

and tasks in the shaping of meaning. Learners compare their version of the truth with that of the instructor and fellow learners in order to get to a new, socially tested version of truth (Kukla 2000). The task or problem is thus the interface between the instructor and the learner (McMahon 1997). This creates a dynamic interaction between task, instructor and learner. This entails that learners and instructors should develop an awareness of each other's viewpoints and then look to own beliefs, standards and values, thus being both subjective and objective at the same time (Savery 1994).

Green and Gredler (2002) emphasize learning as an iterative process, involving discursive, adaptive, interactive, and reflexive qualities. According to them the main focus is on the instructor-student relationship. Other studies, too, argue for the importance of mentoring in the process of learning (Archee and Duin 1995; Brown et al. 1989). The social constructivist model thus emphasizes the importance of the relationship between the student and the instructor in the learning process.

Some learning approaches that could harbour this interactive learning include reciprocal teaching, peer collaboration, cognitive apprenticeships, problem-based instruction, web quests, anchored instruction and other approaches that involve learning with others. 


\subsubsection{Collaboration between learners}

Learners with different skills and backgrounds should collaborate in tasks and discussions in order to arrive at a shared understanding of the truth in a specific field (Duffy and Jonassen 1992).

Most social constructivist models, such as that proposed by Duffy and Jonassen (1992), also stress the need for collaboration among learners, in direct contradiction to traditional competitive approaches. One Vygotskian notion that has significant implications for peer collaboration, is that of the zone of proximal development. Defined as the distance between the actual developmental level as determined by independent problem-solving and the level of potential development as determined through problem-solving under adult guidance or in collaboration with more capable peers, it differs from the fixed biological nature of Piaget's stages of development. Through a process of 'scaffolding' a learner can be extended beyond the limitations of physical maturation to the extent that the development process lags behind the learning process (Vygotsky 1978).

\subsubsection{The importance of context}

The social constructivist paradigm views the context in which the learning occurs as central to the learning itself (McMahon 1997).

Underlying the notion of the learner as an active processor is "the assumption that there is no one set of generalised learning laws with each law applying to all 
University of Pretoria etd - Cooper, J H (2005)

domains" (Di Vesta 1987:208). Decontextualised knowledge does not give us the skills to apply our understandings to authentic tasks because, as Duffy and Jonassen (1992) indicated, we are not working with the concept in the complex environment and experiencing the complex interrelationships in that environment that determine how and when the concept is used. One social constructivist notion is that of authentic or situated learning, where the student takes part in activities which are directly relevant to the application of learning and which take place within a culture similar to the applied setting (Brown et al. 1989). Cognitive apprenticeship has been proposed as an effective constructivist model of learning which attempts to "enculturate students into authentic practices through activity and social interaction in a way similar to that evident, and evidently successful, in craft apprenticeship" (Ackerman 1996:25).

The context in which the learning occurs as well as the social contexts that the learners bring to their learning environment are thus critical to the learning itself (Gredler 1997).

\subsubsection{Assessment}

Holt and Willard-Holt (2000) emphasize the concept of dynamic assessment, which is a way of assessing the true potential of learners that differs significantly from conventional tests. Here the essentially interactive nature of learning is extended to the process of assessment. Rather than viewing assessment as a process carried out by one person, such as an instructor, it is seen as a two-way process involving interaction between both instructor and learner. The role of the assessor becomes 
University of Pretoria etd - Cooper, J H (2005)

one of entering into dialogue with the persons being assessed to find out their current level of performance on any task and sharing with them possible ways in which that performance might be improved on a subsequent occasion. Thus, assessment and learning are seen as inextricably linked and not separate processes (Holt and Willard-Holt 2000).

According to this viewpoint instructors should see assessment as a continuous and interactive process that measures the achievement of the learner, the quality of the learning experience and courseware. Assessment is also an integral part of the learning experience and not a loose-standing process (Gredler 1997). The feedback created by the assessment process serves as a direct foundation for further development. It should not be an intimidating process that causes anxiety in the learner, but rather a supportive process that encourages the learner to want to be evaluated in order for future, more focused development to take place (Green and Gredler 2002).

\subsection{The selection, scope and sequencing of the subject matter}

\subsubsection{Knowledge should be discovered as an integrated whole}

Knowledge should not be divided into different subjects or compartments, but should be discovered as an integrated whole (McMahon 1997; Di Vesta 1987).

This also again underlines the importance of the context in which learning is presented (Brown et al. 1989). According to the above scholars knowledge should 
University of Pretoria etd - Cooper, J H (2005)

not be rigidly compartmentalised into different subjects or categories, but should be presented and discovered as an integrated whole. The reason for this being that the world, in which the learner needs to operate, does not approach one in the form of different subjects, but as a complex myriad of facts, problems, dimensions and perceptions (Ackerman 1996).

\subsubsection{Engaging and challenging the learner}

Learners should constantly be challenged with tasks that refer to skills and knowledge just beyond their current level of mastery. This will capture their motivation and build on previous successes in order to enhance the confidence of the learner (Brownstein 2001). This is in line with Vygotsky's zone of proximal development which can be described as the distance between the actual developmental level (as determined by independent problem-solving) and the level of potential development (as determined through problem-solving under adult guidance or in collaboration with more capable peers) (Vygotsky 1978).

Vygotsky (1978) further promulgated that instruction is good only when it proceeds ahead of development. Then it awakens and rouses to life an entire set of functions which are in the stage of maturing, which lie in the zone of proximal development. It is in this way that instruction plays an extremely important role in development.

In order to fully engage and challenge the learner, the task and the learning environment should reflect the complexity of the environment that the learner should 
University of Pretoria etd - Cooper, J H (2005)

be able to function in at the end of learning. Learners must not only have ownership of the learning or problem-solving process, but of the problem itself (Derry 1999).

Where the sequencing of subject matter is concerned, it is the constructivist viewpoint that the foundations of any subject may be taught to anybody at any stage in some form (Duffy and Jonassen 1992). This means that instructors should first introduce the basic ideas that give life and form to any topic or subject area, and then revisit and build upon these repeatedly. This notion has been extensively used in curricula.

It is also important for instructors to realise that although a curriculum may be set down for them, it inevitably becomes shaped by them into something personal which reflects their own belief systems, their thoughts and feelings about both the content

of their instruction and their learners (Rhodes and Bellamy 1999). Thus, the learning experience becomes a shared enterprise. The emotions and life contexts of those involved in the learning process must therefore be considered as an integral part of learning. The goal of the learner is central in considering what is learned (Brown et al. 1989; Ackerman 1996; Gredler 1997).

\subsubsection{The structuredness of the learning process}

It is important to achieve the right balance between the degree of structure and flexibility that is built into the learning process. Savery (1994) contends that the more structured the learning environment, the harder it is for the learners to construct meaning based on their conceptual understandings. A facilitator should structure the 


\section{University of Pretoria etd - Cooper, J H (2005)}

learning experience just enough to make sure that the students get clear guidance and parameters within which to achieve the learning objectives, yet the learning experience should be open and free enough to allow for the learners to discover, enjoy, interact and arrive at their own, socially verified version of truth.

\subsection{Final remarks}

A social constructivist learning intervention is thus an intervention where contextualised activities (tasks) are used to provide learners with an opportunity to discover and collaboratively construct meaning as the intervention unfolds. Learners are respected as unique individuals, and instructors act as facilitators rather than as teachers. 
University of Pretoria etd - Cooper, J H (2005)

\title{
4. CHAPTER 4: FULL JOURNAL ARTICLE
}

\section{TITLE: $\quad$ A training programme based on the principles of social constructivism and focused on developing people for the future world of work: an evaluation}

\begin{abstract}
Human resource development needs to take cognisance of the unique challenges the workplace of the future will pose for individuals in order to be able to effectively prepare individuals for the future. The objective of this study was to evaluate a training programme that was based on the principles of social constructivism and focused on developing people for the workplace of the future. A non-equivalent groups design with a pre-and post-measurement was used to evaluate the programme. The experimental group consisted of thirty-six individuals and the control group consisted of twenty individuals. The training programme contributed to a significant increase in the creativity, adaptability and self-acceptance of the experimental group (compared with the control group). These characteristics are necessary to succeed in the future workplace. The training programme thus made a valuable contribution to the development of the experimental group for the workplace of the future.
\end{abstract}




\section{Opsomming}

Menslikehulpbron-ontwikkeling moet ag slaan op die unieke uitdagings wat die werksplek van die toekoms aan indiwidue gaan stel ten einde hulle effektief daarvoor voor te berei. Die doel van hierdie studie was om 'n opleidingsprogram, wat op die beginsels van sosiale konstruktivisme gebaseer is en wat ten doel het om indiwidue te ontwikkel vir die werksplek van die toekoms, te evalueer. 'n Nie-ekwivalente groepsontwerp met ' $\mathrm{n}$ voor- en na-meting is gebruik om die opleidingsprogram te evalueer. Die eksperimentele groep het bestaan uit ses en dertig indiwidue terwyl die kontrole groep uit twintig indiwidue bestaan het. Die opleidingsprogram het bygedra tot ' $n$ beduidende toename in die eksperimentele groep (vergeleke met die kontrole groep) se kreatiwiteit, aanpasbaarheid en self-aanvaarding. Hierdie eienskappe is noodsaaklik vir sukses in die werksplek van die toekoms. Die opleidingsprogram het dus ' $n$ waardevolle bydrae gelewer om die eksperimentele groep te ontwikkel vir die werksplek van die toekoms.

\subsection{Introduction}

During recent years the world has experienced unprecedented technological advancements, which left indelible marks on how people live and work (Ridderstråle and Nordström 2004). This rapid rate of change is increasing exponentially (Molebash and Fisher 2003) and poses challenges that the workforce never had to deal with before (Koschmann 2000). This means that the workplace that people were trained for ten years ago does not exist anymore and nor will the workplace as we know it today exist in ten years' time (Grulke 2001; Ridderstråle and Nordström 2004). Traditional methods of education and training, however, are not regarded as 
University of Pretoria etd - Cooper, J H (2005)

being sufficient for preparing individuals for the future workplace (Senge 2000; Dixon-Kraus 1996). If these methods of education are not sufficient to prepare people for the workplace of the future (Senge 2000; Dixon-Kraus 1996), how should one go about training people for a workplace that does not yet exist (Cetron 1999)? One educational methodology that is suggested as a possible solution is the social constructivist theory of Lev Semenovich Vygotsky (Smith 2003; Holt and Willard-Holt 2000).

\subsection{Purpose of study}

The purpose of this study is to evaluate a training intervention that is based on the principles of social constructivism and that focuses on developing individuals for the future world of work. The study thus aims at validating one of the following hypotheses:

1. Zero-hypothesis: The intervention effected no positive change in the participants pertaining to the characteristics needed to succeed in the workplace of the future.

2. Alternative hypothesis: The intervention effected a positive change in the participants pertaining to the characteristics needed to succeed in the workplace of the future.

Attention is firstly given to a theoretical description of the future workplace as well as the characteristics needed to succeed in such a workplace. Secondly, a theoretical discussion of social constructivism takes place. Finally, emphasis is placed on the methodology that was applied in order to fulfil the purpose of the study. 
University of Pretoria etd - Cooper, J H (2005)

\subsection{Theoretical background}

\subsubsection{The future world of work and the characteristics required for success}

When thinking about the world of the future, technology is seen as the major driver of change (Marginson 2000; Adler 1992). Although the possibilities of nano- and biotechnology are widely being speculated about (Grulke 2001; Hiemstra 1999), one only needs to consider the growing capabilities of current, everyday information and communication technologies to realise the immensity of the speed of change (Drucker 1998). Molebash and Fisher (2003) emphasize the impact that Moore's law (that the power of microprocessors doubles every 18 months) will have on the global economy and society at large. If one adds to this the increasing connectivity provided by the internet, with bandwidth doubling every nine months (Geldenhuys 2004), one moves to a world that is smaller than ever before, and a workforce that has more information at its fingertips than ever dreamt possible (Drucker 1998). It thus becomes clear that communication and information technologies like the internet, laptop and handheld computers, cell phones and wireless applications will have an ever-increasing impact on the way the workplace is organised (Koschmann 2000). Add to this the increasing changes in societal institutions and values, and one has a totally new world of work with radically different rules (Ridderstråle and Nordström 2004).

One characteristic of the workplace of the future is that the emphasis is moving from large corporations to smaller organisations and stronger relationships (Epstein 1998). The organisation of the future will be nimble, quick and resilient (Wagner 
2002). It will consist of extremely fluid work teams and workers will work in different teams and in different roles simultaneously (Bass 2000). These teams will be highly diverse and dispersed across the globe (Kerka 2000). Furthermore, as rapid change and chaotic uncertainty are becoming an integral part of doing business, the organisation that wants to survive the future, needs to be able to embrace chaos and be radically innovative about doing everyday business (Grulke 2001).

Also, in a world where information abounds, an extremely high value will be placed on people who can create value out of knowledge and meaning out of information (Brownstein 2001). In order to fuel this, the physical layout of offices and work-team structures will be designed to enhance communication and collaboration, where individuals can creatively stimulate new ideas and concepts (Herman and Gioia 1998). Continuous training and development will also become critical aspects of the workplace of the future (Brownstein 2001; Cetron 1999).

The workplace of the future that has been depicted so far will demand specific characteristics of individuals. In order to excel in the future world of work, one needs to be passionate about change (Boyatzis 1999). It is not merely about being able to cope with change, but about being totally adaptable, viewing change as a positive inevitability, embracing change and creating change (McGinn and McCormick 1999). This includes the ability to cope with the stress and frustration that accompanies chaos, uncertainty and change (Ridderstråle and Nordström 2004). Individuals will also need the ability to creatively and innovatively seek and create opportunities as well as the risk proneness to pursue them (Herman and Gioia 1998). The person who is capable of imaginatively spotting new opportunities as they arise, capitalize 
on them and move on to the next opportunity, will be in high demand in the marketplace of the future (Kerka 2000).

In addition to the above, the individual of the future needs to be assertive, confident and self-acceptant and needs to know him/herself and his/her strengths, weaknesses and goals - feeling competent and well-liked by others (Branden 1997). Characteristics such as integrity, authenticity, honesty and consistency will also gain an even higher importance in future as these are all vital ingredients for managing networks and relationships (Boyatzis 1999). People with the ability to maintain a healthy balance between people- and task-orientation will be able to create workplaces that are pleasant, peaceful and non-threatening amidst an uncertain and changing environment (Epstein 1998; Branden 1997). Also, in a world where business and work will depend increasingly on relationships and the way one manages those relationships, one begins to understand the value of attributes such as love, kindness and compassion (Humphreys 2003). Seeking the best interest of the other party and going out of one's way to serve are all connected to the concept of kindness (Epstein 1998). In a workplace that will become increasingly diverse, a kind and respectful demeanour will improve one's chances of having fruitful relationships with team members from different cultures, religions and backgrounds (Humphreys 2003).

A high level of internal motivation, pro-activity and drive as well as the ability to inspire and motivate others will also improve one's chances of thriving in the new world of work (Land and Jarman 1992; Pickett 1998). Specific traits associated with motivation are tenacity, self-discipline, focus and energy (Porter 1968). Finally, in a 
world of abundance of information and exponential growth in knowledge, it is impossible to imagine success without a continuous drive for learning and selfdevelopment (Branden 1997; Senge 1993; Marginson 2000). This includes an investigative, inquisitive and creative approach to everyday tasks and challenges (Koschmann 2000). The following diagram gives a broad overview of the literature pertaining to the world of the future, the workplace of the future and the characteristics needed by individuals to succeed in such a workplace.

Figure 4.1: The world, workplace and the successful individual of the future

\begin{tabular}{|c|c|c|}
\hline \multicolumn{3}{|c|}{ IN THE FUTURE } \\
\hline $\begin{array}{l}\text { The world } \\
\text { will be characterized by }\end{array}$ & $\begin{array}{l}\text { The workplace } \\
\text { will need to be }\end{array}$ & $\begin{array}{l}\text { The individual } \\
\text { should have }\end{array}$ \\
\hline Technological & Flexible; & A passion for change; \\
\hline revolutions; & Small, nimble and quick; & An opportunity- \\
\hline Unprecedented change; & Radically innovative; & orientation; \\
\hline Constructive chaos; & Relationship focused; & Confidence; \\
\hline Abounding information & Extremely diverse; & Integrity; \\
\hline and communication & Dispersed and virtual; & Kindness and love; \\
\hline ability; & Valuing skills & Motivation; \\
\hline Endless new & & A passion for learning \\
\hline opportunities; & & \\
\hline Increasing globalization & & \\
\hline
\end{tabular}




\subsubsection{Social Constructivism}

The constructivist movement, as defined and developed by Jean Piaget (Flavell and Piaget 1963), has grown essentially from dissatisfaction with educational methods where rote memorisation, regurgitation of facts and the division of knowledge into different subjects (Dixon-Kraus 1996), led to a situation where learners were not necessarily able to apply what they had learned in real life (Senge 2000). The main underlying assumption of Piaget's cognitive constructivism is that individuals are actively involved right from birth in constructing personal meaning that is their own personal understanding from their experiences (Holt and Willard-Holt 2000). This action-based theory is thus more concerned with the process of learning than with what is learned (McMahon 1997).

Where cognitive constructivism focuses on a process of learning where the individual constructs her/his own version of truth based on active assimilation and interpretation (Savery 1994), social constructivism, as fathered by Vygotsky (1978), adds another component to the learning process: social interaction. The individual's version of truth thus needs to be tested against other individuals' versions in order for the group to arrive at a higher order version of truth (Derry 1999). Social constructivism thus embraces a dynamic interaction between instructors, learners and tasks where learners can create their own truth due to the interaction with others (Sternberg and Williams 1998). The task or problem becomes the interface between the instructor and the learner (Archee and Duin 1995). The relationship between the instructor and the learner thus becomes central to the learning process (Brown et al. 1989). 
Social constructivism also emphasizes the importance of culture and context in understanding what is happening in society and constructing knowledge based on this understanding (Derry 1999; McMahon 1997). It does not only acknowledge the uniqueness and complexity of the learner, but actually encourages, utilises and rewards it as an integral part of the learning process (Gredler 1997; Wertsch 1997). It is also argued by social constructivists that the responsibility for learning should reside increasingly with the learner and that the learner should be actively involved in the learning process (Von Glasersfeld 1989).

According to the social constructivist approach, instructors have to adapt to the role of being facilitators and not teachers (Brownstein 2001). Where a teacher gives a didactic lecture which covers the subject matter, a facilitator helps the learner to get to his or her own understanding of the content (Rhodes and Bellamy 1999). The emphasis thus turns away from the instructor and the content, and towards the learner (Prawat and Floden 1994). The context in which the learning occurs is also regarded as central to the learning itself (McMahon 1997; Di Vesta1987).

Decontextualised knowledge does not provide the skills to apply our understandings to authentic tasks (Duffy and Jonassen 1992). One social constructivist notion is that of authentic or situated learning, where the student takes part in activities which are directly relevant to the application of learning and which take place within a culture similar to the applied setting (Brown et al. 1989; Ackerman 1996; Gredler 1997). Savery (1994) also contends that the more structured the learning environment, the harder it is for learners to construct meaning based on their conceptual understandings. Vygotsky (1978) further promulgated that instruction is good only 
when it proceeds ahead of development, or, as he called it, within the 'zone of proximal development'. As far as assessment is concerned, social constructivism argues for a dynamic assessment process in which the assessment process forms a dialogical part of the learning process (Holt and Willard-Holt 2000).

\subsection{Methodology}

\subsubsection{Research design}

A Non-equivalent Groups Design (NEGD) was followed, based on a pre-test and post-test of both an experimental and a control group (Trochim 2002). Only the experimental group was exposed to the intervention. The control group was included in the study to control the possible history-effect as a threat to the internal validity of the study. The non-equivalent groups design is a quasi-experimental design and is widely used in social research. It differs from a pure experimental design in that the groups are not randomly assigned (Trochim 2002).

\subsubsection{Sampling}

In this study 36 individuals were included in the experimental group on the basis of having already been enrolled for the six-month training intervention that was to be evaluated. The participants were all between the ages of eighteen and twenty-five and were from different cultural backgrounds. Twenty participants were white and seventeen were black. Fourteen participants were female and twenty-two male. The experimental group's participants were not engaged in any formal secondary or 
tertiary studies at the time, although all of them had completed secondary school and some of them already had tertiary qualifications. The control group consisted of twenty individuals, ranging from twenty to twenty-two in age. All of the control group members were white, ten were male and ten female. The control group members were all second-year commerce students from the human resource management class at the University of Pretoria. Although they were not exposed to the intervention under discussion, they continued as usual with their normal university classes and routine. The main difference between the experimental group and the control group thus is the fact that the experimental group participated in the sixmonth training intervention under discussion and that the control group was not exposed to the training intervention.

\subsubsection{The training intervention}

The training intervention was designed and presented by a private educational initiative consisting of team members from various fields such as psychology, education, theology and business. The intervention was a six-month full-time (8:00 16:00) programme and was funded by private investors as well as the participants themselves. The programme aimed to develop individuals to be successful in the workplace of the future. The first and main goal of the programme was to develop certain mindsets / characteristics that could form the foundation for developing the participants for the workplace of the future. Although these characteristics were seldom explicitly focused on, the programme design and training methodology aimed to develop these characteristics as an indirect consequence of the day-to-day 
training interventions. The following diagram gives a schematic overview of what the programme focused on:

Figure 4.2: Overview of the training curriculum

\begin{tabular}{|c|c|}
\hline \multirow{11}{*}{ 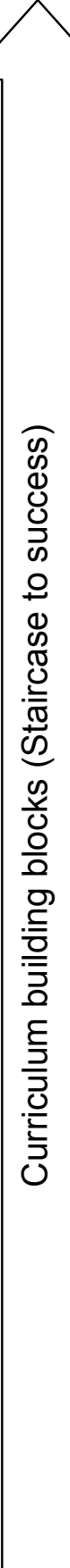 } & 6. Success \\
\hline & $\begin{array}{l}\text { Happiness } \\
\text { My motivation } \\
\text { My confidence } \\
\text { My self-assessment ability } \\
\text { Product creation } \\
\text { Creative problem-solving }\end{array}$ \\
\hline & 5. Learning \\
\hline & $\begin{array}{l}\text { Analysis } \\
\text { Evaluation } \\
\text { Apply } \\
\text { Understand } \\
\text { Know }\end{array}$ \\
\hline & 4. Thinking \\
\hline & $\begin{array}{l}\text { Philosophy } \\
\text { Statistical reasoning } \\
\text { Systems thinking } \\
\text { Research }\end{array}$ \\
\hline & 3. Learning ability \\
\hline & $\begin{array}{l}\text { Action learning } \\
\text { Experiential learning } \\
\text { Challenge cycle } \\
\text { My style \& type of intelligence } \\
\text { Being taught }\end{array}$ \\
\hline & 2. Skill \\
\hline & $\begin{array}{l}\text { Lead } \\
\text { Group functions } \\
\text { Sell } \\
\text { Present } \\
\text { Speak } \\
\text { Write } \\
\text { Read } \\
\text { Computers } \\
\text { 1. Mindset }\end{array}$ \\
\hline & $\begin{array}{l}\text { Passion for change } \\
\text { Opportunity-orientation } \\
\text { Confidence } \\
\text { Integrity } \\
\text { Kindness and love } \\
\text { Motivation } \\
\text { Passion for learning }\end{array}$ \\
\hline
\end{tabular}


The training methodology that was followed could broadly be divided into two main categories, namely facilitated group interventions and facilitated one-on-one interventions. While the group interventions allowed for the participants to explore and master the desired learning objectives collaboratively, the one-on-one sessions took place between a learner and a learning partner (coach) and allowed the learner to reflect on her/his progress in relation to her/his personal future goals and objectives.

The group sessions made extensive use of activities that engaged the learners in a process of discovery and group reflection. Some of these activities were simulated while others were real life experiences. Many activities were also created by the learners themselves, which created considerable buy-in from learners into the learning process. One example of a simulated set of activities that was used is a high ropes adventure experience. These activities took the learners out of their comfort zones and stimulated discussions around group dynamics, leadership, interpersonal relationships, uncertainty, change, personal goal setting and risk. One example of a real life activity that was used was the ' $R 50$ business'. Each student received R50 on a Thursday morning and on the following Monday they had to report on the profit they had made. Principles regarding entrepreneurship and business opportunities were derived from this. The subject matter was thus experienced by the learners as an integrated whole, situated within the context in which it would be used again in future.

Facilitators steered the process and created the environment for the learners to arrive at their own conclusions. The learners also came from diverse cultural and 
academic backgrounds, which extensively influenced discussions and conclusions. Assessment was an ongoing dialogical process between peers, the learning-partner (coach) and the learner, the facilitator and learner and self-assessment. Assessment never took place by means of a test or exam and was continuously used to set new development targets and to celebrate targets that had been reached. The following table compares the practical implementation of the training intervention with the principles of social constructivism:

Figure 4.3: Comparison between social constructivism and the training programme

\begin{tabular}{|c|c|c|}
\hline Aspect & Social Constructivist Theory & Training programme \\
\hline $\begin{array}{l}\text { The nature of } \\
\text { the learner }\end{array}$ & $\begin{array}{l}\text { - Each learner is unique. } \\
\text { she background, culture and } \\
\text { symbol systems (e.g. language) } \\
\text { of the learner form an integral } \\
\text { part of the learning process. } \\
\text { - The learner has ownership of } \\
\text { and is actively involved (as a } \\
\text { whole person) in the learning } \\
\text { process. } \\
\text { - The focus is with the learner } \\
\text { and her/his agenda. }\end{array}$ & $\begin{array}{l}\text { - Each learner had a unique learning } \\
\text { programme, based on her/his } \\
\text { personal development objectives. } \\
\text { - In group discussions attention was } \\
\text { given to get all points of view. } \\
\text { - Activities and topics were selected } \\
\text { based on the learners' wants and } \\
\text { needs. This was done in collaboration } \\
\text { with the learning-partner (coach). }\end{array}$ \\
\hline $\begin{array}{l}\text { The role of the } \\
\text { instructor }\end{array}$ & $\begin{array}{l}\text { - The instructor facilitates the } \\
\text { learning process and does not } \\
\text { teach content. } \\
\text { - The instructor creates the } \\
\text { environment for learning to take } \\
\text { place. } \\
\text { - The instructor keeps the focus } \\
\text { on the learner and her/his } \\
\text { agenda. } \\
\text { - The relationship between } \\
\text { instructor and learner is vital. }\end{array}$ & $\begin{array}{l}\text { Facilitators were selected and trained } \\
\text { according to the key requirements of } \\
\text { the facilitation process. } \\
\text { - Each facilitator was measured } \\
\text { according to the extent that she/he: } \\
\circ \text { Elicited buy-in and ownership } \\
\circ \text { Focused on the learners } \\
\circ \text { Customised for the learners' needs } \\
\circ \text { Creatively synthesised after session } \\
\circ \text { Created and managed energy levels } \\
\circ \text { Evoked and sustained interaction } \\
\circ \text { Facilitated respect for different } \\
\text { views. } \\
\circ \text { Linked with overall programme }\end{array}$ \\
\hline
\end{tabular}




\begin{tabular}{|c|c|c|}
\hline Aspect & Social Constructivist Theory & Training programme \\
\hline $\begin{array}{l}\text { The nature of } \\
\text { the learning } \\
\text { process }\end{array}$ & $\begin{array}{l}\text { - Learning is an active process of } \\
\text { dynamic interaction between } \\
\text { instructor, task and learner. } \\
\text { - The learner creates a personal } \\
\text { version of truth that gets tested } \\
\text { by means of dialogue between } \\
\text { the learner, her/his peers and } \\
\text { the instructor. } \\
\text { - Learners engage in situation- } \\
\text { specific tasks that facilitate the } \\
\text { learning process. }\end{array}$ & $\begin{array}{l}\text { - Group interventions consisted of } \\
\text { context-specific simulated and real } \\
\text { tasks as well as feedback and } \\
\text { discussion. } \\
\text { - Problem/solution-based tasks were } \\
\text { used for learners to utilise various } \\
\text { competencies simultaneously. } \\
\text { Facilitated dialogue between learners } \\
\text { was used to debrief and unpack the } \\
\text { collaborative learning processes. }\end{array}$ \\
\hline $\begin{array}{l}\text { The selection } \\
\text { and } \\
\text { sequencing of } \\
\text { subject matter }\end{array}$ & $\begin{array}{l}\text { - Content is not experienced as } \\
\text { separate subjects, but as an } \\
\text { integrated whole. } \\
\text { - The level of difficulty of tasks } \\
\text { and complexity of subject } \\
\text { matter should be just above the } \\
\text { learner's current level of } \\
\text { mastery. }\end{array}$ & $\begin{array}{l}\text { The programme designer built subject } \\
\text { matter into integrated experiences } \\
\text { and assignments. Learning-partners } \\
\text { (coaches) gave feedback regarding } \\
\text { the level of difficulty/complexity the } \\
\text { learner should be exposed to. }\end{array}$ \\
\hline $\begin{array}{l}\text { The } \\
\text { assessment } \\
\text { process }\end{array}$ & $\begin{array}{l}\text { - Assessment is a dynamic } \\
\text { process. } \\
\text { - It forms part of the learning } \\
\text { process and does not threaten } \\
\text { the learner. }\end{array}$ & $\begin{array}{l}\text { Assessment consisted of peer } \\
\text { assessment, self-assessment, } \\
\text { dialogical assessment with learning } \\
\text { partners and facilitators. Each } \\
\text { learner's development plan was } \\
\text { updated after each assessment. }\end{array}$ \\
\hline
\end{tabular}

\subsubsection{The research process}

Based on the literature review specific characteristics were identified as necessary to succeed in the workplace of the future. A battery of psychometric instruments was compiled to measure these characteristics. The pre-test for the experimental group was done on the first day of the training programme and the post-test on the last day. There was thus a six-month period between the pre- and post-test for the 
experimental group. The control group also had a period of six months between the pre- and post- test, but were not exposed to the training intervention. The control group's tests were administered during class time as they all continued with their day-to-day university classes over the six-month period. The testing conditions for both groups were very similar as both groups were tested under controlled, classroom circumstances.

\subsubsection{Measurement instruments}

The psychometric battery that was used as the assessment instrument comprised of sixteen tests from the Situation Specific Evaluation Expert (SpEEx) and Potential Index Batteries (PIB) series. These individual tests that made up the psychometric battery all have well researched and satisfactory reliability (ranging between 0.58 and 0.92 ) and validity (ranging between 0.70 and 0.94 ) statistical records (Schaap 2004). The tests measured the following constructs: creativity, stress tolerance, type A/B behaviour, frustration tolerance, self-acceptance, adaptability, internal / external actualisation, conformity / non-conformity and the demonstrative, samaritarian, persevering and evaluative social styles. The following table indicates how the constructs that were measured are linked to the characteristics (or mindsets, as they were called in the training curriculum) that the training programme focused on: 


\section{Figure 4.4: Constructs measured}

\begin{tabular}{|c|c|c|}
\hline $\begin{array}{c}\text { Construct } \\
\text { measured by } \\
\text { psychometric } \\
\text { battery }\end{array}$ & $\begin{array}{l}\text { Construct description according to the } \\
\text { developers of the psychometric battery } \\
\text { (Erasmus and Schaap 2002) }\end{array}$ & $\begin{array}{c}\text { Characteristics that } \\
\text { the training } \\
\text { programme } \\
\text { focused on }\end{array}$ \\
\hline Creativity & $\begin{array}{l}\text { Imagination; insight and innovation; new } \\
\text { approaches to old problems. }\end{array}$ & $\begin{array}{l}\text { Opportunity- } \\
\text { orientation } \\
\text { Passion for change }\end{array}$ \\
\hline Stress & $\begin{array}{l}\text { Controls physical and mental symptoms of } \\
\text { stress adequately in uncertain situations. }\end{array}$ & $\begin{array}{l}\text { Passion for change } \\
\text { Confidence }\end{array}$ \\
\hline A/B Behaviour & $\begin{array}{l}\text { Well-balanced orientation towards people and } \\
\text { tasks; creates climate for peaceful, non- } \\
\text { threatening and stress-free environment. }\end{array}$ & $\begin{array}{l}\text { Kindness and love } \\
\text { Integrity }\end{array}$ \\
\hline Frustration tolerance & $\begin{array}{l}\text { Cope with frustration caused by uncertainty and } \\
\text { provocation. }\end{array}$ & Passion for change \\
\hline Self Acceptance & $\begin{array}{l}\text { Views self as acceptable, accepted and well- } \\
\text { liked by others; feel competent and confident. }\end{array}$ & Confidence \\
\hline Adaptability & $\begin{array}{l}\text { Accepts change and adapts to change; views } \\
\text { change as positive; opposes other's views; } \\
\text { generates new ideas; creative and imaginative. }\end{array}$ & $\begin{array}{l}\text { Passion for change } \\
\text { Opportunity- } \\
\text { orientation }\end{array}$ \\
\hline Internal actualisation & $\begin{array}{l}\text { Considers different options, makes decisions } \\
\text { and takes action out of own accord; leads for } \\
\text { others to follow; achieves. }\end{array}$ & Motivation \\
\hline External actualisation & $\begin{array}{l}\text { Capacity to follow; adheres to rules and } \\
\text { regulations; accept external authority. }\end{array}$ & Motivation \\
\hline $\begin{array}{l}\text { Conformity / Non- } \\
\text { conformity }\end{array}$ & $\begin{array}{l}\text { Adheres to rules and regulations (or not); } \\
\text { accepts traditional views (or not). }\end{array}$ & $\begin{array}{l}\text { Passion for change } \\
\text { Integrity }\end{array}$ \\
\hline Demonstrative & $\begin{array}{l}\text { Verbally expressive; inspiring; manipulative; } \\
\text { convincing; talkative; spontaneous; open- } \\
\text { minded. }\end{array}$ & $\begin{array}{l}\text { Motivation } \\
\text { Confidence } \\
\text { Passion for change }\end{array}$ \\
\hline Samaritarian & $\begin{array}{l}\text { Displays sympathy, empathy, companionship; } \\
\text { supportive; assisting; co-operative. }\end{array}$ & Kindness and love \\
\hline Perseverance & $\begin{array}{l}\text { Adamant; insisting; driving; risk-taking; task- } \\
\text { minded; punctual; assertive; arrogant; intolerant; } \\
\text { challenging. }\end{array}$ & $\begin{array}{l}\text { Motivation } \\
\text { Opportunity- } \\
\text { orientation } \\
\text { Confidence }\end{array}$ \\
\hline Evaluative & $\begin{array}{l}\text { Asks questions; investigates; attends to detail; } \\
\text { insists on quality. }\end{array}$ & Passion for learning \\
\hline
\end{tabular}




\subsubsection{Statistical analysis}

The Mann-Whitney U-test was used to determine the significance of the differences between the variation that took place in the experimental group and the control group over the six-month period between the pre- and post-tests. In this test, each treated entity is compared to each control entity. It is used when any treated entity can be validly compared to any control entity. The interpretation of the results of the MannWhitney $\mathrm{U}$ test is similar to that of the normal t-test, except that the U-test makes use of the sum of rank orders rather than the statistical mean. The statistical decision criterion was set on the level of $\alpha=0,05$. Where results were statistically significant, the practical significance was also calculated. For differences between averages the practical significance level was set at $d=0,5$ (medium effect size, Cohen 1988). The practical significance (d) pertaining to the comparison of the experimental and the control groups is represented as follows (Steyn 1999):

$$
d=\left(\bar{X}_{E}(\text { Post })-\bar{X} E\left(P_{r e}\right)\right) / S \text { Max }
$$

Where

$d=$ Practical significance

$\mathrm{X}($ Post $)=$ The mean of the post-measurement of the experimental group

$\mathrm{X}(\mathrm{Pre})=$ The mean of the pre-measurement of the experimental group

$\mathrm{S}_{\mathrm{Max}}=$ The maximum standard deviation between the pre- and post- measurement

of the experimental group. 


\subsection{Results}

Table 4.1: Differences between the pre- and post-evaluations of the experimental and control group pertaining to the constructs measured

\begin{tabular}{|c|c|c|c|c|c|c|c|c|c|c|}
\hline \multirow[b]{3}{*}{ Construct } & \multicolumn{4}{|c|}{ Control Group $(\mathrm{N}=20)$} & \multicolumn{6}{|c|}{ Experimental Group $(\mathrm{N}=36)$} \\
\hline & \multicolumn{2}{|c|}{ Pre-test } & \multicolumn{2}{|c|}{ Post-test } & \multicolumn{2}{|c|}{ Pre-test } & \multicolumn{2}{|c|}{ Post-test } & \multirow[b]{2}{*}{$\mathrm{P}$} & \multirow[b]{2}{*}{$d$} \\
\hline & Mean & $\begin{array}{l}\text { Std. } \\
\text { Dev. }\end{array}$ & Mean & $\begin{array}{l}\text { Std. } \\
\text { Dev. }\end{array}$ & Mean & $\begin{array}{l}\text { Std. } \\
\text { Dev. }\end{array}$ & Mean & $\begin{array}{l}\text { Std. } \\
\text { Dev. }\end{array}$ & & \\
\hline Creativity & 107,75 & 13,89 & 106,55 & 17,28 & 109,22 & 22,87 & 120,08 & 13,15 & ${ }^{*} 0,01$ & ${ }^{\prime} 0,47$ \\
\hline Stress mental & 39,95 & 13,21 & 40,50 & 13,63 & 33,89 & 14,67 & 31,33 & 13,44 & 0,19 & \\
\hline Stress physical & 88,50 & 24,38 & 89,85 & 25,81 & 77,67 & 26,93 & 73,06 & 26,61 & 0,76 & \\
\hline A/B Behaviour & 147,25 & 26,93 & 157,50 & 29,88 & 146,36 & 41,62 & 160,11 & 31,72 & 0,92 & \\
\hline Frustration tolerance & 85,20 & 9,00 & 86,70 & 13,07 & 85,64 & 20,06 & 87,97 & 17,76 & 0,63 & \\
\hline Self Acceptance & 72,35 & 12,84 & 75,50 & 13,28 & 82,64 & 12,42 & 88,44 & 11,72 & ${ }^{*} 0,04$ & 0,47 \\
\hline Adaptability & 59,75 & 12,03 & 57,80 & 13,37 & 67,36 & 17,89 & 82,69 & 16,46 & ${ }^{*} 0,00$ & "0,86 \\
\hline Internal actualisation & 74,05 & 12,88 & 78,30 & 14,55 & 85,11 & 14,84 & 93,72 & 12,12 & 0,49 & \\
\hline External actualisation & 61,90 & 13,30 & 59,60 & 13,48 & 55,78 & 17,82 & 45,94 & 13,97 & 0,12 & \\
\hline (Non)conformity & 83,70 & 11,67 & 81,40 & 10,46 & 74,03 & 10,62 & 73,39 & 10,28 & 0,62 & \\
\hline Demonstrative & 10,30 & 6,19 & 8,95 & 6,00 & 11,08 & 6,63 & 12,58 & 6,60 & ${ }^{*} 0,01$ & 0,23 \\
\hline Samaritarian & 12,25 & 6,05 & 12,05 & 6,05 & 12,58 & 5,02 & 10,17 & 4,94 & 0,06 & \\
\hline Perseverance & 6,65 & 3,54 & 7,00 & 3,91 & 7,56 & 5,57 & 8,50 & 5,67 & 0,74 & \\
\hline Evaluative & 8,70 & 5,08 & 10,10 & 6,30 & 8,25 & 4,20 & 7,50 & 4,84 & ${ }^{*} 0,04$ & $-0,18$ \\
\hline
\end{tabular}

* - Difference is statistically significant: $p \leq 0,05$

' - Difference is practically meaningful: $d=0,5$ (medium effect size)

" - Difference is practically meaningful: $d=0,8$ (large effect size)

Table 1 shows a statistically significant difference between the pre-and post-

measurements on the creativity, self-acceptance, adaptability, demonstrative and evaluative scales. The direction of the change in the experimental group was positive in the cases of creativity, adaptability and self-acceptance and negative in the case of the evaluative social style. The differences on the adaptability (large effect size), self-acceptance (medium effect size) and creativity (medium effect size) scales are also practically meaningful. 


\subsection{Conclusion}

It seems from the results as if the training intervention had a practically significant positive impact on the adaptability, creativity and self-acceptance of the experimental group in comparison to that of the control group. The zero-hypothesis for these dimensions could thus be rejected and the alternative hypothesis can be accepted. Participants in the programme were thus significantly more capable of adapting to a continuously changing environment than they were before participating in the training programme. Participants were also able to display higher levels of creativity and creative approaches to problem-solving than they had been prior to the intervention. The levels of confidence and acceptance of self were also significantly increased. The attributes of creativity (Grulke 2001; Brownstein 2001; Cetron 1999; Ridderstråle and Nordström 2004), adaptability (Boyatzis 1999; Herman and Gioia 1998; Kerka 2000; McGinn and McCormick 1999) and self-acceptance (Branden 1997; Senge 1993; Koschmann 2000; Marginson 2000; Land and Jarman 1992; Pickett 1998) are all regarded as essential for succeeding in the workplace of the future.

The demonstrative and evaluative social styles of the participants also underwent a statistically significant (though not a practically meaningful) change. This means that participants were more willing to assertively express themselves and to take part in group discussions than they were before the intervention. They were also less evaluative in their social approach, meaning that they would take decisions quicker and with less regard to having every bit of information before taking action. Being willing and able to express oneself, take risks, get involved and create action are 
also regarded as essential attributes for succeeding in the workplace of the future (Ridderstråle and Nordström 2004; Boyatzis 1999; Epstein 1998; Branden 1997).

However, according to the results, the training programme did not have a statistically significant impact on constructs such as stress and frustration tolerance, type A/B behaviour, internal/external locus of control, conformity/non-conformity and the social styles called Perseverance and Samaritarian. For these dimensions the zerohypothesis is accepted. The training intervention was thus partially successful in developing the characteristics that were measured.

This study had three main weaknesses: Firstly, due to logistical constraints, the groups were not assigned randomly. Secondly, due to the cost of the intervention which limited the number of participants to the programme, a Solomon four-group design could not be followed. The Solomon four-group design would require an additional two control groups that did not take part in the pre-test evaluation (Trochim 2002). This would control the effect that the pre-test might have had on the participants. The limited sample size also makes it difficult to generalise these results to the wider population. The results could also have been different if the control group was not exposed to any learning interventions during the evaluation period. The control group did however continue with their normal undergraduate curriculum while the experimental group was exposed to the training programme under discussion.

A third possible weakness of the study lies more at a philosophical level. The training programme that was evaluated was based on the educational principles of social 
constructivism - a markedly post-modern philosophy and approach. In addition to this the context, which forms the backdrop for this study, is that of the workplace of the future - a context that certainly tends increasingly to the 'post' side of modernism. The study thus evaluates a post-modern training programme, based on a post-modern educational philosophy, in order to determine whether or not it effectively develops people for a post-modern workplace. Yet, the methodology which is applied in executing the study is very modernistic in its approach. It is a methodology where human characteristics are broken down into psychometric constructs which are (almost mechanistically) measured and statistically analysed. This becomes especially problematic when one tries to seamlessly link each construct that was measured with the exact nuances that the literature associates with the successful individual of the future. The question is: Can the world of metaphor, story and dialogical understanding validly be subjected to the measurement instruments and research methods of the world of mechanistic and systematic understanding? On the other hand, in order to effectively communicate with the modernistic remnants in our present-day institutions, one needs to be willing to express oneself in the language and idiom best understood by those institutions. It would be interesting, though, to see how a qualitative or even narrative research model would have evaluated this training programme.

Further research that could also add valuable insights might be a post-post assessment to indicate the sustainability of the changes that took place. This could most effectively be joined with a qualitative assessment in order to determine the real level of success the experimental group achieved in the future workplace over a longer period of time. From the researcher's subjective experience of the 
experimental group's development, the question of age also became of interest. Does age have an impact on the efficiency of a social constructivist learning experience? The age-differential in the two groups was too small to make any conclusions in this regard, although there were stages in the programme where the older participants seemed to be getting more value than their younger classmates.

The purpose of this research was to determine whether or not a training programme, which was based on the principles of social constructivism, was effective in developing individuals for the future world of work. In order to determine this, a psychometric test battery was used to measure specific constructs that are related to what scholars currently regard as being essential characteristics for success in the future workplace. Although many questions regarding developing people for the future workplace still remain unanswered, this study provides a framework through which to approach training and development in organisations. As all organisations are confronted with the challenges and uncertainties of the future, the way in which people are trained and developed should be re-evaluated on a continuous basis. This training programme used a social constructivist approach that acknowledges the fact that people learn best when doing, discovering and sharing. In this way the divide between learning and real life decreases and we are able to also develop 'softer' characteristics such as adaptability, self-acceptance and creativity. 
University of Pretoria etd - Cooper, J H (2005)

\subsection{References}

Adler, P. S. (Ed.) (1992) Technology and the Future of Work, New York: Oxford University Press.

Archee, R. and Duin, A. H. (1995) The WWW and Distance Education Convergence or Cacophony? Paper presented at the AUUG '95 \& AsiaPacific WWW '95 Conference and Exhibition, Sydney, Australia.

Bass, B. M. (2000) The Future of Leadership in Learning Organizations. Journal of Leadership Studies, 7(3), 18.

Boyatzis, R. E. (1999) 'Self-Directed Change and Learning as a Necessary Meta competency for success and Effectiveness in the 21st Century', in Sims, R. and Veres, J.G. (Eds.). Keys to Employee Success in the Coming Decades. Westport, CN: Greenwood Publishing.

Branden, N. (1997) 'Self-Esteem in the Information Age'. The Organization of the Future, San Francisco: Jossey-Bass.

Brown, J. S., Collins, A. and Duguid, P. (1989) Situated cognition and the culture of learning. Educational Researcher, 18(1), 32-41.

Brownstein, B. (2001) Collaboration: The Foundation of Learning in the Future. Education, 122(2), 240. 
University of Pretoria etd - Cooper, J H (2005)

Cetron, M. (1999) Fair or Foul? Forecasts for Education. School Administrator, 56, 6.

Cohen, J. (1988) Statistical power analysis for the behavioral sciences (Revised ed.). Orlando, CA: Academic Press.

Derry, G. N. (1999) What Science Is and How It Works. Princeton, NJ: Princeton University Press.

Di Vesta, F. J. (1987) The Cognitive Movement and Education. In J. A. Glover \& R. R. Ronning (Eds.), Historical Foundations of Educational Psychology (pp. 203-233). New York: Plenum Press.

Dixon-Kraus, L. (1996) Vygotsky in the Classroom: Mediated Literacy Instruction, White Plains, NY: Longman Publishers.

Drucker, P. (1998, November) The Future That Has Already Happened. The Futurist, 32, 16.

Duffy, T. M. and Jonassen, D. H. (1992) Constructivism: New Implications for Instructional Technology. In T. M. Duffy \& D. H. Jonassen (Eds.), Constructivism and the Technology of Instruction: A Conversation (pp. 116). Hillsdale, NJ: Lawrence Erlbaum Associates, Inc.

Epstein, J. H. (1998, November) The Relationship Economy. The Futurist, 32, 8. 
University of Pretoria etd - Cooper, J H (2005)

Erasmus, P. F. and Schaap, P. (2002, September) 'Situation specific evaluation expert - job profiling inventory', Potential Index Associates cc.

Flavell, J. H. and Piaget, J. (1963) Developmental Psychology of Jean Piaget. Princeton, $\mathrm{NJ}$ : Van Nostrand.

Geldenhuys, P. (2004) A Few Trends that will Shape Our Future. TomorrowToday ezine. http://www.tomorrowtoday.biz

Gredler, M. E. (1997) Learning and instruction: Theory into practice (3rd ed). Upper Saddle River, NJ: Prentice-Hall.

Grulke, W. (2001) Radical Innovation. South Africa: Thorold's Africana Books.

Grulke, W. (2000) 10 Lessons from the Future. South Africa: Financial Times/Prentice Hall.

Herman, R. E. and Gioia, J. L. (1998, December) Making Work Meaningful: Secrets of the Future-Focused Corporation. The Futurist, 32, 24.

Hiemstra, G. (1999) A Letter from 2028: An Older and Smaller World. Scenario and Strategy Planning. October 1999: 29 - 31

Holt, D. G. and Willard-Holt, C. (2000). Let's Get Real - Students Solving Authentic Corporate Problems. Phi Delta Kappan, 82(3), 243. 
University of Pretoria etd - Cooper, J H (2005)

Humphreys, T. (2003) Whose Life are You Living? Gill \& Macmillan

Kerka, S. (2000) Future of Work. Myths and Realities. 11:1-2

Koschmann, T. (2000) The Future of Work. Journal of the Learning Sciences, 9(4), 501-503.

Land, G. and Jarman, B. (1992, July/August) Future Pull: The Power of Vision and Purpose. The Futurist, 26, 25.

Marginson, S. (2000) The Changing Nature and Organisation of Work, and the Implications for Vocational Education and Training in Australia. Leabrook, Australia: National Centre for Vocational Education Research.

McGinn, D. and McCormick, J. (1999) 'Your Next Job', Newsweek, 133, 5:42-51.

McMahon, M. (1997, December) Social Constructivism and the World Wide Web - A Paradigm for Learning. Paper presented at the ASCILITE conference. Perth, Australia.

Molebash, P. and Fisher, D. (2003) Teaching and Learning Literacy with Technology. Reading Improvement, 40(2), 63.

Pickett, L. (1998) Competencies and Managerial Effectiveness: Putting Competencies to Work. Public Personnel Management, 27(1), 103. 
University of Pretoria etd - Cooper, J H (2005)

Porter, L. W. (1968) Management by Motivation, Personnel Psychology, Vol. 21 Issue 4:528.

Prawat, R. S. and Floden, R. E. (1994) Philosophical Perspectives on Constructivist Views of Learning. Educational Psychologist, 29(1), 37-48.

Rhodes, L. K. and Bellamy, G. T. (1999) Choices and Consequences in the Renewal of Teacher Education. Journal of Teacher Education, 50(1), 17.

Ridderstråle, J. and Nordström, K. A. (2004) Karaoke Capitalism. Bookhouse Publishing.

Savery, J. (1994, May) What is problem-based learning? Paper presented at the meeting of the Professors of Instructional Design and Technology, Indiana State University, Bloomington, IN.

Schaap, P. (2004) 'The reliability and validity statistics of the PIB-SpEEx', Research report, Department of Human Resource Management, University of Pretoria.

Senge, P. (2000) Schools that Learn: A Fieldbook for Teachers, Administrators, Parents and Everyone Who Cares About Education (A Fifth Discipline Resource), Nicholas Brealey Publishing. 
University of Pretoria etd - Cooper, J H (2005)

Senge, P. M. and Kofman, F. (1993) Communities of commitment: The heart of learning organizations. Organizational Dynamics, 22:4-20.

Smith, P. J. (2003) Workplace learning and flexible delivery. Review of Educational Research, 73(1), 53-88.

Sternberg, R. J. and Williams, W. M. (Eds.). (1998) Intelligence, Instruction, and Assessment: Theory into Practice. Mahwah, NJ: Lea Lawrence Erlbaum Associates.

Steyn, H.S. (1999) Praktiese betekenisvolheid: Die gebruik van effekgroottes. Wetenskaplike bydraes Reeks B: Natuurwetenskappe Nr. 117. Potchefstroom: PU vir $\mathrm{CHO}$.

Trochim, W. M. K. (2002) Nonequivalent groups analysis. The Research Methods Knowledge Base. http://www. socialresearchmethods.net/kb/statnegd.htm.

Von Glasersfeld, E. (1989) Constructivism in education. In T. Husen \& N. Postlewaite (Eds.), International Encyclopedia of Education [Suppl.], (pp.162-163). Oxford, England: Pergamon Press.

Vygotsky, L. (1978) Mind in Society: The Development of Higher Psychological Processes MA: Harvard University Press. 
University of Pretoria etd - Cooper, J H (2005)

Wagner, C. G. (2002, November/December) World View 2002: Futures Unlimited. The World Won't Work Unless the World Works Together, Concluded Several Speakers at the World Future Society's Annual Meeting in Philadelphia. The Futurist, 36, 48.

Wertsch, J.V. (1997) Vygotsky and the social formation of the mind. Cambridge, MA: Harvard University Press. 
University of Pretoria etd - Cooper, J H (2005)

\section{BIBLIOGRAPHY}

Ackerman, E. (1996). Perspective Taking and Object Construction: Two Keys to Learning. In Y. Kafai \& M. Resnick (Eds.), Constructionism in Practice: Designing, Thinking, and Learning in a Digital World (pp. 25-35). New Jersey: Lawrence Earbaum Associates.

Adler, P. S. (Ed.) (1992) Technology and the Future of Work. New York: Oxford University Press.

Archee, R. and Duin, A. H. (1995) The WWW and Distance Education Convergence or Cacophony? Paper presented at the AUUG '95 \& AsiaPacific WWW '95 Conference and Exhibition, Sydney, Australia.

Bass, B. M. (2000) The Future of Leadership in Learning Organizations. Journal of Leadership Studies, 7(3), 18.

Boyatzis, R. E. (1999) `Self-Directed Change and Learning as a Necessary Meta competency for success and Effectiveness in the 21st Century', in Sims, R. and Veres, J.G. (Eds.). Keys to Employee Success in the Coming Decades. Westport, CN: Greenwood Publishing.

Branden, N. (1997) 'Self-Esteem in the Information Age'. The Organization of the Future, San Francisco: Jossey-Bass. 
University of Pretoria etd - Cooper, J H (2005)

Brown, J. S., Collins, A. and Duguid, P. (1989). Situated cognition and the culture of learning. Educational Researcher, 18(1), 32-41.

Brownstein, B. (2001) Collaboration: The Foundation of Learning in the Future. Education, 122(2), 240.

Cetron, M. (1999) Fair or Foul? Forecasts for Education. School Administrator, 56, 6.

Chewning, R, C., Eby, J. W. and Roels, S. J. (1990) Business through the eyes of faith, San Francisco: Harper.

Challenger, J. A. (1998, October) There Is No Future for the Workplace. The Futurist, 32, 16+. Retrieved June 26, 2004, from Questia database, http://www.questia.com.

Coates, J. F., Jarratt, J. and Mahaffie, J. B. (1991, May/June) Future Work. The Futurist, 25, 9+. Retrieved June 26, 2004, from Questia database, http://www.questia.com.

Cohen, J. (1988) Statistical power analysis for the behavioral sciences (Revised ed.). Orlando, CA: Academic Press.

Derry, G. N. (1999) What Science Is and How It Works. Princeton, NJ: Princeton University Press. 
University of Pretoria etd - Cooper, J H (2005)

Di Vesta, F. J. (1987) The Cognitive Movement and Education. In J. A. Glover \& R. R. Ronning (Eds.), Historical Foundations of Educational Psychology (pp. 203-233). New York: Plenum Press.

Dixon-Kraus, L. (1996) Vygotsky in the Classroom: Mediated Literacy Instruction, White Plains, NY: Longman Publishers.

Drucker, P. (1998, November) The Future That Has Already Happened. The Futurist, $32,16$.

Duffy, T. M. and Jonassen, D. H. (1992) Constructivism: New Implications for Instructional Technology. In T. M. Duffy \& D. H. Jonassen (Eds.), Constructivism and the Technology of Instruction: A Conversation (pp. 116). Hillsdale, NJ: Lawrence Erlbaum Associates, Inc.

Eisler, R. (2000, January) The Partnership School of the Future. Tikkun, 15, 62. Retrieved June 26, 2004, from Questia database, http://www.questia.com.

Epstein, J. H. (1998, November) The Relationship Economy. The Futurist, 32, 8.

Erasmus, P. F. and Schaap, P. (2002, September) 'Situation specific evaluation expert - job profiling inventory', Potential Index Associates cc.

Ernest, P. (1991) Philosophy of Mathematics Education, London: Falmer. 
University of Pretoria etd - Cooper, J H (2005)

Flavell, J. H. and Piaget, J. (1963) Developmental Psychology of Jean Piaget. Princeton, NJ: Van Nostrand.

Geldenhuys, P. (2004) A Few Trends that will Shape Our Future. TomorrowToday ezine. http://www.tomorrowtoday.biz

Green, J. (2000, October 23) The Online Education Bubble. The American Prospect, 11, 32. Retrieved June 26, 2004, from Questia database, http://www.questia.com.

Green, S. K. and Gredler, M. E. (2002) A Review and Analysis of Constructivism for School-Based Practice. School Psychology Review, 31(1), 53+. Retrieved June 30, 2004, from Questia database, http://www.questia.com.

Gredler, M. E. (1997) Learning and instruction: Theory into practice (3rd ed). Upper Saddle River, NJ: Prentice-Hall.

Grulke, W. (2001) Radical Innovation. South Africa: Thorold's Africana Books.

Grulke, W. (2000) 10 Lessons from the Future. South Africa: Financial Times/Prentice Hall.

Heckman, J. J. (1999, Spring) Doing It Right: Job Training and Education. Public Interest, 86+. Retrieved June 26, 2004, from Questia database, http://www.questia.com. 
University of Pretoria etd - Cooper, J H (2005)

Herman, R. E. and Gioia, J. L. (1998, December) Making Work Meaningful: Secrets of the Future-Focused Corporation. The Futurist, 32, 24.

Hiemstra, G. (1999) A Letter from 2028: An Older and Smaller World. Scenario and Strategy Planning. October 1999: 29 - 31.

Holt, D. G. and Willard-Holt, C. (2000) Let's Get Real - Students Solving Authentic Corporate Problems. Phi Delta Kappan, 82(3), 243.

Humphreys, T. (2003) Whose Life are You Living? Gill \& Macmillan.

Jennings, L. (2001, January) Alternative Visions for the Future University. The Futurist, 35, 58. Retrieved June 26, 2004, from Questia database, http://www.questia.com.

Katz, R. N. (2000) The 'E' Is for Everything: E-commerce, E-business, and E-learning in Higher Education. Jossey-Bass.

Kerka, S. (2000) Future of Work. Myths and Realities. 11:1-2.

Koschmann, T. (2000) The Future of Work. Journal of the Learning Sciences , 9(4), 501-503.

Kukla, A. (2000) Social Constructivism and the Philosophy of Science. New York: Routledge. 
University of Pretoria etd - Cooper, J H (2005)

Land, G. and Jarman, B. (1992, July/August) Future Pull: The Power of Vision and Purpose. The Futurist, 26, 25.

Marginson, S. (2000) The Changing Nature and Organisation of Work, and the Implications for Vocational Education and Training in Australia. Leabrook, Australia: National Centre for Vocational Education Research.

McGinn, D. and McCormick, J. (1999) 'Your Next Job', Newsweek, 133, 5:42-51.

McMahon, M. (1997, December) Social Constructivism and the World Wide Web - A Paradigm for Learning. Paper presented at the ASCILITE conference. Perth, Australia.

Molebash, P. and Fisher, D. (2003) Teaching and Learning Literacy with Technology. Reading Improvement, 40(2), 63.

Pickett, L. (1998) Competencies and Managerial Effectiveness: Putting Competencies to Work. Public Personnel Management, 27(1), 103.

Porter, L. W. (1968) Management by Motivation, Personnel Psychology , Vol. 21 Issue 4:528.

Prawat, R. S. and Floden, R. E. (1994) Philosophical Perspectives on Constructivist Views of Learning. Educational Psychologist , 29(1), 37-48. 
University of Pretoria etd - Cooper, J H (2005)

Rhodes, L. K. and Bellamy, G. T. (1999) Choices and Consequences in the Renewal of Teacher Education. Journal of Teacher Education, 50(1), 17.

Rhodes, C. and Garrick, J. (2002) Economic metaphors and working knowledge: enter the 'cogito-economic' subject. Human Resource Development International 5:1 (2002) pp 87-97.

Ridderstråle, J. and Nordström, K. A. (2004) Karaoke Capitalism. Bookhouse Publishing.

Savery, J. (1994, May) What is problem-based learning? Paper presented at the meeting of the Professors of Instructional Design and Technology, Indiana State University, Bloomington, IN.

Schaap, P. (2004) 'The reliability and validity statistics of the PIB-SpEEx', Research report, Department of Human Resource Management, University of Pretoria.

Senge, P. (2000) Schools that Learn: A Fieldbook for Teachers, Administrators, Parents and Everyone Who Cares About Education (A Fifth Discipline Resource), Nicholas Brealey Publishing.

Senge, P. M. and Kofman, F. (1993) Communities of commitment: The heart of learning organizations. Organizational Dynamics ,22:4-20. 
University of Pretoria etd - Cooper, J H (2005)

Smith, P. J. (2003) Workplace learning and flexible delivery. Review of Educational Research, 73(1), 53-88.

Steffe, L. P. and Gale, J. (Eds.) (1995) Constructivism in Education. Hillsdale, NJ: Lawrence Erlbaum Associates.

Sternberg, R. J. and Williams, W. M. (Eds.).(1998) Intelligence, Instruction, and Assessment: Theory into Practice. Mahwah, NJ: Lea Lawrence Erlbaum Associates.

Steyn, H.S. (1999) Praktiese betekenisvolheid: Die gebruik van effekgroottes. Wetenskaplike bydraes Reeks B: Natuurwetenskappe Nr. 117. Potchefstroom: PU vir $\mathrm{CHO}$.

Trochim, W. M. K. (2002) Nonequivalent groups analysis. The Research Methods Knowledge Base. http://www. socialresearchmethods.net/kb/statnegd.htm.

Von Glasersfeld, E. (1989) Constructivism in education. In T. Husen \& N. Postlewaite (Eds.), International Encyclopedia of Education [Suppl.], (pp.162-163). Oxford, England: Pergamon Press.

Vygotsky, L. (1978) Mind in Society: The Development of Higher Psychological Processes MA: Harvard University Press. 
University of Pretoria etd - Cooper, J H (2005)

Wagner, C. G. (2002, November/December) World View 2002: Futures Unlimited! the World Won't Work Unless the World Works Together, Concluded Several Speakers at the World Future Society's Annual Meeting in Philadelphia. The Futurist, 36, 48.

Wertsch, J.V. (1997) Vygotsky and the social formation of the mind. Cambridge, MA: Harvard University Press. 